\title{
6. CLASTIC, DIAGENETIC, AND METAMORPHIC LITHOLOGIES OF A SUBSIDING CONTINENTAL BLOCK: CENTRAL PERU FOREARC ${ }^{1}$
}

\author{
LaVerne D. Kulm, ${ }^{2}$ Todd M. Thornburg, ${ }^{2}$ Erwin Suess, ${ }^{2}$ Johanna Resig, ${ }^{3}$ and Patricia Fryer ${ }^{3}$
}

\begin{abstract}
A geologic sampling program was conducted on the central Peru margin in two areas, one centered around a latitude of $9^{\circ} \mathrm{S}$ (Trujillo and Yaquina basins) and the other near $11.5^{\circ} \mathrm{S}$ (Lima Basin). High-grade metamorphic basement crops out along the upper-slope ridge in the $9^{\circ} \mathrm{S}$ area between the Yaquina and Trujillo basins and consists of quartz-biotite gneiss and schist. Similar metamorphic lithologies were recovered in the Ballena and Delfin industry wells that were located over the outer-shelf high along the landward flank of the Trujillo Basin. Conglomerate dredged from the upperslope ridge contains rounded metamorphic pebbles, barnacle debris, and an articulated oyster shell. Most likely this conglomerate formed in a lagoonal or littoral environment as a basal lag deposit overlying continental basement. The barnacle-oyster conglomerate indicates subsidence from near sea level to present water depths of 900 to $1200 \mathrm{~m}$. This subsidence probably predates the late Miocene because rocks younger than $6 \mathrm{Ma}$ indicate no vertical translation since deposition. Low-grade metamorphics (slate and metapelite) recovered from the mid-to- lower slope in the $9^{\circ} \mathrm{S}$ survey area represent either a seaward extension of the crystalline continental block or the exhumed part of an accretionary complex. However, associated conglomerates containing quartzite and andesite pebbles in sparry calcite cement probably are derived from local continental source terranes. Rocks as old as middle Eocene (43-46 m.y.) are exposed along a prominent transverse structure on the midslope at $9.5^{\circ} \mathrm{S}$ (water depth of $3400-4000 \mathrm{~m}$ ) and appear to correlate with the Chira Formation of northwest Peru. A minimum of $1300 \mathrm{~m}$ of subsidence since middle Miocene time (12-13 Ma) is documented at this locality.

The most profound subsidence in late Neogene and Quaternary time occurred in the $11.5^{\circ} \mathrm{S}$ survey area. Late Miocene-Pliocene benthic foraminifers that originally lived in water depths ranging from 150 to $500 \mathrm{~m}$ were dredged from outcrops on the seaward flank of the Lima Basin in today's water depths of 2600 to $2800 \mathrm{~m}$. Consequently, the metamorphic block underlying the Lima Basin subsided from 2100 to $2650 \mathrm{~m}$ during the last $6 \mathrm{~m}$.y., giving minimum and maximum rates of 350 and $442 \mathrm{~m} / \mathrm{m}$.y., respectively. About $3900 \mathrm{~m}$ of subsidence is indicated during approximately the same time period by benthic foraminifer assemblages contained in mudstones dredged from the trench-slope break in 4100 to $4600 \mathrm{~m}$ of water, which yielded an average subsidence rate of $650 \mathrm{~m} / \mathrm{m} . \mathrm{y}$.

Dark gray to dark brown, aphanitic carbonates (dolomicrite, lime micrite, and calcareous mudstone) were the most prevalent lithologies recovered from the forearc basins of both survey areas. Organic-rich mudstones derived from coastal upwelling probably make up the bulk of the Neogene stratigraphy throughout much of the forearc, based on the low seismic velocities of the basin deposits, but the more resistant carbonate interbeds were preferentially dredged from the seafloor. Carbonates form by the pervasive cementation of porous upwelling sediments in the subsurface diagenetic environment in association with biogenic decomposition of organic carbon. The composition of the diagenetic carbonates varies from calcite $\left(2-12 \mathrm{~mol} \% \mathrm{MgCO}_{3}\right)$ to dolomite $\left(46-53 \mathrm{~mol} \% \mathrm{MgCO}_{3}\right)$. Calcite mineralogies are more abundant in the Trujillo Basin, while dolomite is more typical of the Lima Basin. Likewise, carbonates of the former basin are characterized by isotopically light $\delta^{13} \mathrm{C}$ values $\left(-2\right.$ to $-37 \%$ PDB) and the latter by heavy $\delta^{13} \mathrm{C}$ values $(-15$ to $+18 \%$ ). Most of the $\delta^{18} \mathrm{O}$ values fall between +4.8 and $+7.4 \%$, which indicates precipitation at low temperatures in the shallow subsurface; a few samples from the $9^{\circ} \mathrm{S}$ survey area are unusually depleted in ${ }^{18} \mathrm{O}$ (to $-2.3 \%$ ) and must have precipitated from pore fluids of much higher temperature, or from meteoric waters associated with subaerial exposure surfaces.

Some of the more indurated mudstones and cemented carbonates have been extensively fractured in response to tectonism and dewatering within the forearc basins. Much larger quantities of brecciated carbonates were obtained from the Trujillo Basin than from the Lima Basin, which is consistent with the pervasive brittle deformation evident in seismic-reflection records of the former basin. Microbrecciated dolomicrite, dredged from the seaward edge of the continental block and the presumed accretionary prism, is cut by multiple generations of cemented fractures. The apparent trenchward increase in brecciation intensity in the $11.5^{\circ} \mathrm{S}$ area may reflect the progressive collapse of the continental block from the toe of the forearc toward the hinterland in response to subduction erosion.
\end{abstract}

\section{INTRODUCTION}

The basement framework, vertical tectonics, and configuration of Cenozoic sedimentary basins control the formation of depositional and diagenetic lithologies in the central Peru forearc. The basins of the continental shelf (Sechura, Salaverry, and East Pisco) have a floor of block-faulted Paleozoic or Precambrian metamorphic basement. An outer-shelf structural high $(\mathrm{OSH})$ trends parallel to the Andean strike, forming the seaward flank of these shelf basins. The basins of the upper continental

\footnotetext{
${ }^{1}$ Suess. E., von Huene, R., et al., 1988. Proc. ODP, Init. Repts., 112: College Station, TX (Ocean Drilling Program).

2 College of Oceanography, Oregon State University, Corvallis, OR 97331.

${ }^{3}$ Hawaii Institute of Geophysics, University of Hawaii, Honolulu, HI 96822.
}

slope (Trujillo, Lima, and West Pisco) lie between the OSH and an upper-slope ridge (USR), and the Yaquina Basin occupies a midslope position seaward of the Trujillo Basin (Fig. 1; Thornburg and Kulm, 1981; Thornburg, 1985). The lower continental slope consists of a network of anastomosing structural ridges and small ponded basins.

A SeaMARC-II side-scanning survey was conducted by the Hawaii Institute of Geophysics (HIG) in two areas centered around a latitude of $11.5^{\circ} \mathrm{S}$ and $9^{\circ} \mathrm{S}$ in central Peru. Objectives were to outline the surface morphology and rock outcrops of the continental slope and trench (Fig. 1, areas A and B; Hussong et al., this volume). A coincidental multichannel seismicreflection (MCS) survey was also conducted by HIG to detail the subsurface structure and stratigraphy (Moore and Taylor, this volume; Ballesteros et al., this volume). Using the SeaMARC 


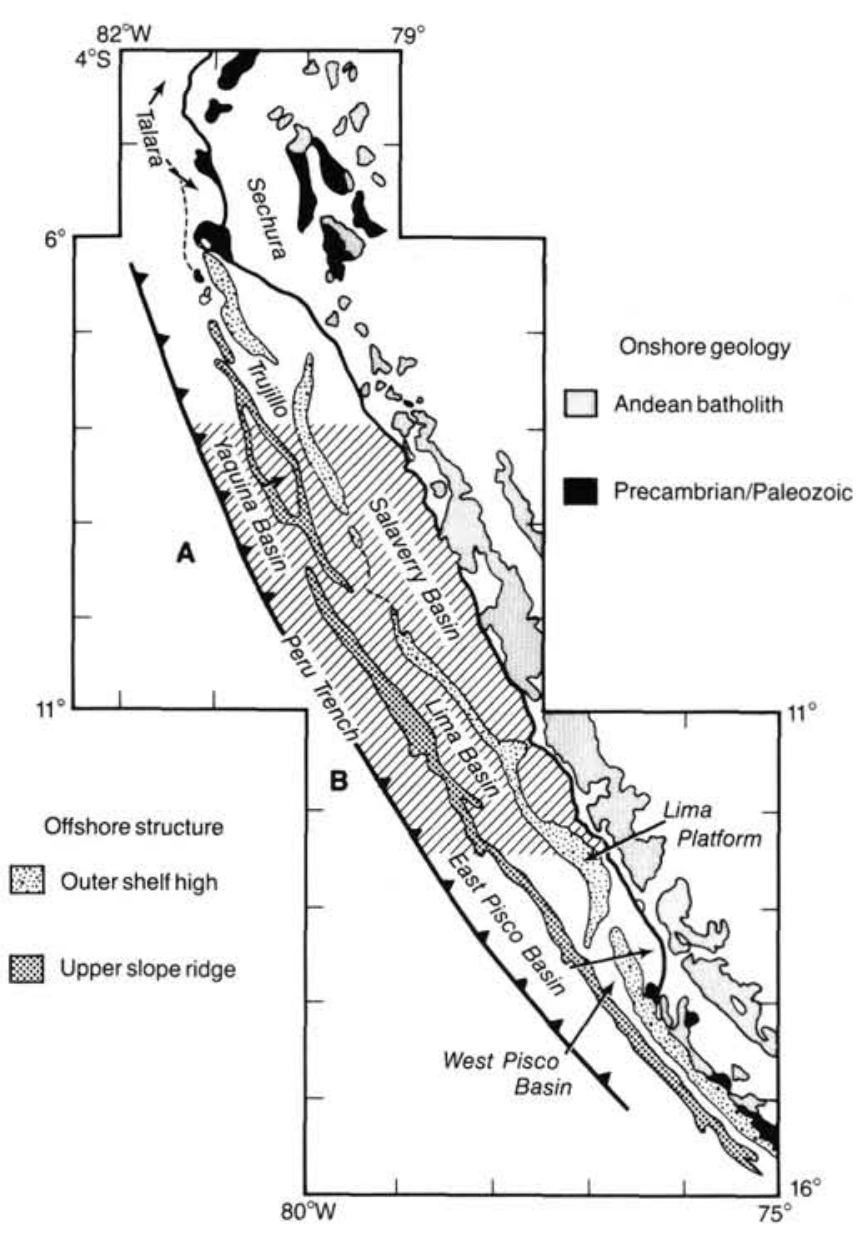

Figure 1. Major forearc basins of the coast, shelf, and upper slope of the Peru Continental Margin, with onshore and offshore structures that control their distribution (after Thornburg and Kulm, 1981). Crosshatched pattern outlines site-survey areas in the central Peru forearc; $\mathrm{A}=$ Trujillo-Yaquina Basin area $\left(9^{\circ} \mathrm{S}\right) ; \mathrm{B}=$ Lima Basin area $\left(11.5^{\circ} \mathrm{S}\right)$.

mosaics and the shipboard-monitored MCS records, we conducted a sediment- and rock-sampling program in water depths ranging from 125 to $5440 \mathrm{~m}$. Tens to hundreds of meters of strata are locally exposed along structural highs on the continental margin.

The objectives of this study were to sample the rock outcrops identified in the side-scanning images and seismic records (1) to determine the lithologies and ages of the sedimentary deposits within the slope basins, (2) to study the authigenic formation of dolomite within the clastic-biogenic sediments of the basins, (3) to determine the nature and age of the basement rocks that underlie the slope basins, and (4) to ascertain the tectonic movements (i.e., subsidence and uplift) of the forearc region. The regional sampling coverage acquired during the site-survey program helped scientists to select drilling sites and provided extensive spatial control, which complements the subsurface borehole data recovered during Leg 112 on the Peru margin. Here, we present the preliminary results of the site-survey sampling program and the preliminary interpretations of the post-cruise laboratory analyses.

\section{DATA ACQUISITION AND METHODS}

We attempted a total of 25 dredges (designated 8506 DR \#) and successfully recovered 21 rock samples (Fig. 2; Table 1); some dredges contained several hundred pounds of material.
Dredges obtained on previous cruises (designated 7706 DR \# or DRAG) are also included to complete the data set for our survey areas. A total of 15 cores were attempted and 11 recovered sediment (Table 2).

Dredged rocks were slabbed, cores were opened, and the lithologies of all samples were described on board the vessel so that the sampling program could be modified as new data were obtained. This technique was productive and expedited our postcruise studies in the laboratory. Samples were shared with the Peruvian scientists who participated in the cruise.

The rock samples from the dredges and cores were analyzed using a variety of techniques and procedures. The mineral composition of the carbonate lithologies was determined by X-ray diffraction techniques and the stable-isotope composition by carbon and oxygen mass spectrometry at Oregon State University. The texture and composition of clastic, carbonate, and metamorphic lithologies were studied in hand specimen and in thin section. The microfossil content of selected sedimentary samples was studied by Johanna Resig. Patricia Fryer described the thin sections of the metamorphic rocks.

We were careful to select benthic microfossil samples from homogeneous or laminated muds and mudstones that exhibited no sedimentary structures indicative of slumping or gravity-flow processes (e.g., contorted or graded beds). Size-sorting and abrasion, which may be imparted by sediment transport, were not evident in the processed microfossil assemblages. When calculating subsidence amounts and rates, we assumed that microfossil assemblages were not subjected to post-depositional, downslope remobilization, but were preserved in situ in the stratigraphic sequence from which they were recovered. Compatible paleodepth determinations across different lithologies or ages at a given dredge site are good evidence that the subsidence estimates are accurate.

\section{TRUJILLO-YAQUINA BASIN SURVEY AREA (9 ${ }^{\circ}$ S)}

Horst-like basement structures trending subparallel to the Andean structural grain-the outer-shelf high (OSH) and the upper-slope ridge (USR) - delineate the major forearc basins of north-central Peru (Figs. 1 and 2). The basement structures can be identified in the side-scanning mosaic by reflections from rock exposures along seaward-facing escarpments that are often fault-controlled (Hussong et al., this volume). Pre-Andean ( $\mathrm{Pa}-$ leozoic and Precambrian) continental metamorphic rocks were recovered from the $\mathrm{OSH}$ in industry drill holes at $9^{\circ} \mathrm{S}$ (Fig. 3) and island exposures at $12^{\circ} \mathrm{S}$ (Kulm et al., 1981). Site-survey dredge DR-34 recovered massive amounts of quartz-biotite schist and gneiss from the USR, extending the continental massif beneath and seaward of the Trujillo Basin (Fig. 4). Small fragments of mica schist and metamorphic-bearing conglomerate were also sampled from the USR along strike at Site DR-35. Highly sheared and recrystallized metapelite dredged from the lower slope at Site DR-30 represents either a seaward extension of the continental block or the exhumed part of an accretionary complex. Conglomerates bearing quartzite and andesite pebbles in the same dredge are more clearly continental in origin. Substantial thicknesses of overburden must have been removed to expose these low-grade metamorphics along the trench-slope break.

The recovery of a shallow-water conglomerate at Site DR-35, located over the USR (Fig. 3), suggests that this part of the margin experienced up to $1000 \mathrm{~m}$ of subsidence. The conglomerate contains numerous components that indicate deposition within a lagoonal or littoral environment-a large articulated oyster, abundant barnacle debris, and rounded metamorphic pebbles (Fig. 5). This lithology probably formed as a transgressive lag deposit lying directly over basement or was shed from a nearby basement high on the USR. Therefore, the rock has probably 

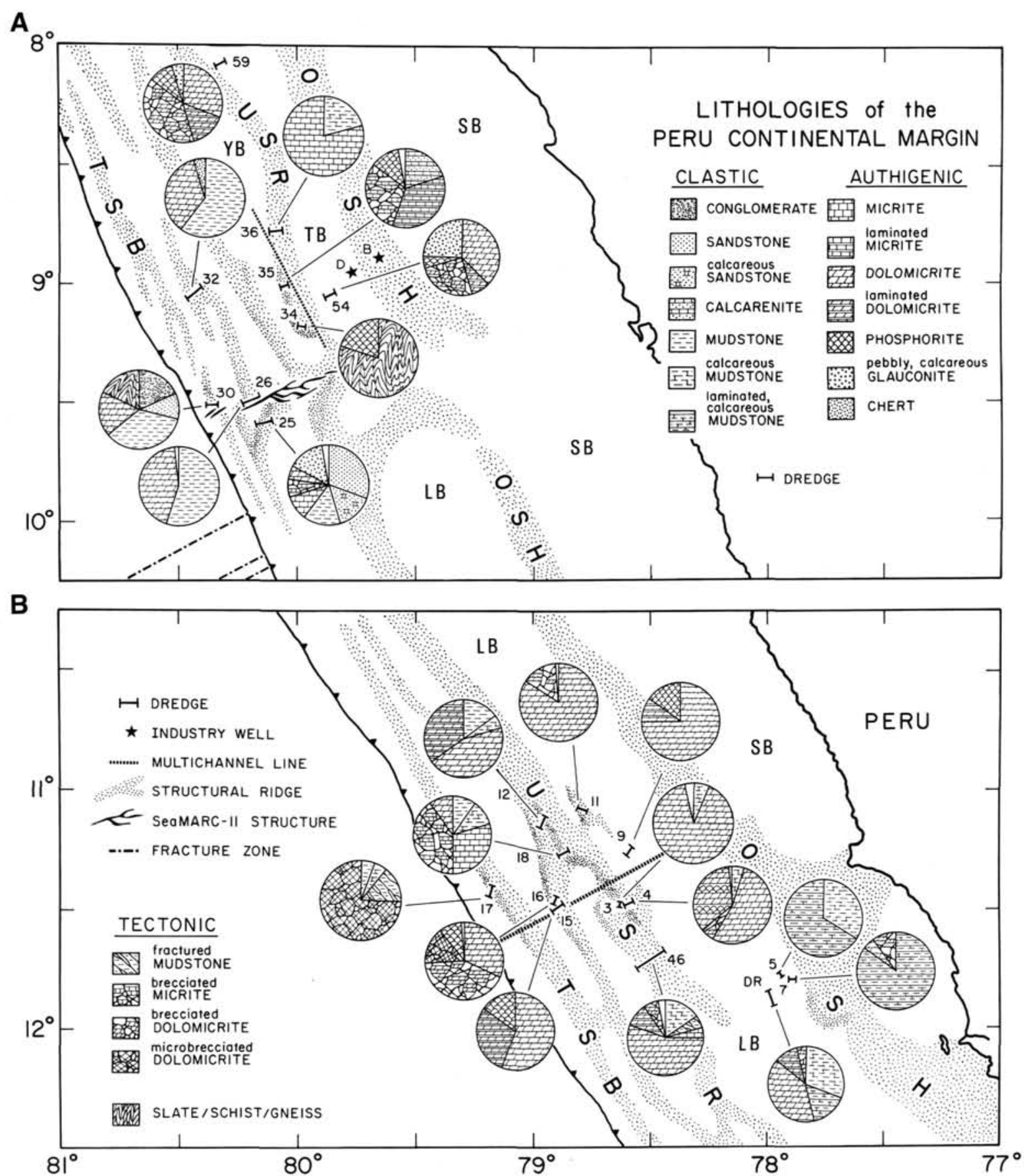

Figure 2. A) Lithologies and dredge locations in the northern survey area (see Figure 1A). Pie diagrams indicate volume percentage of rock types in each dredge, although the actual amount of sample recovered varies among dredges and usually decreases with water depth. Industry drill holes of Figure 3 and MCS seismic profiles of Figures 4 and 8 are located. Distribution of structural ridges (stippled pattern) is modified from Thornburg (1985); SeaMARC-II side-scanning structure from Hussong et al. (this volume). $\mathrm{OSH}=$ outer-shelf high; USR = upper-slope ridge; TSB = trench-slope break; $\mathrm{SB}=$ Salaverry Basin; TB $=$ Trujillo Basin; YB $=$ Yaquina Basin; LB = Lima Basin. B) Lithologies and dredge locations in the southern survey area.

subsided from near sea level to its present water depth of 930 to $1190 \mathrm{~m}$ and presumably predates the overlying late Miocene to Pliocene (6 to $2 \mathrm{~m} . \mathrm{y}$.) carbonate rocks that show no measurable vertical movement (Table 3; Kulm et al., 1981). The conglomerate contains biogenic siliceous clasts that have undergone diagenetic transformation to opal-CT.

An east-west structure, prominently displayed in the SeaMARC mosaic near the transition zone between the Lima and Trujillo basins at about $9^{\circ} 30^{\prime} \mathrm{S}$ (Fig. 2; Hussong et al., this volume), produced the most diverse lithologies yet dredged from the Peru margin. DR-25, collected in a water depth of 3355 to $3940 \mathrm{~m}$, contained terrigenous sandstone, mudstone, limestone, dolomite, brecciated limestone, and minor metamorphic rock fragments. Aside from minor quantities of coarse clastic rocks in DR-30, sandstones were dredged exclusively from Site DR-25. This site had more sandstones than all other sampling stations to date 
Table 1. Location of dredge samples collected during Moana Wave cruise 8506, Wecoma cruise 7706, and Navy Drag along the central Peru Continental Margin.

\begin{tabular}{|c|c|c|c|c|c|c|c|}
\hline \multirow[b]{2}{*}{ Cruise } & \multirow[b]{2}{*}{ Sample/Dredge } & \multicolumn{3}{|c|}{ Start } & \multicolumn{3}{|c|}{ End } \\
\hline & & $\begin{array}{l}\text { Lat. } \\
\text { (S) }\end{array}$ & $\begin{array}{c}\text { Long. } \\
\text { (W) }\end{array}$ & $\begin{array}{c}\text { Water } \\
\text { depth } \\
\text { (m) }\end{array}$ & $\begin{array}{l}\text { Lat. } \\
\text { (S) }\end{array}$ & $\begin{array}{l}\text { Long. } \\
\text { (W) }\end{array}$ & $\begin{array}{c}\text { Water } \\
\text { depth } \\
\text { (m) }\end{array}$ \\
\hline Drag & DR1 & $11^{\circ} 50.5^{\prime}$ & $78^{\circ} 00.0^{\prime}$ & 1200 & $11^{\circ} 50.5^{\prime}$ & $78^{\circ} 00.0^{\prime}$ & 850 \\
\hline 7706 & DR46 & $11^{\circ} 40.9^{\prime}$ & $78^{\circ} 30.6^{\prime}$ & 2263 & $11^{\circ} 38.2^{\prime}$ & $78^{\circ} 29.6^{\prime}$ & 1639 \\
\hline 7706 & DR48 & $11^{\circ} 46.7^{\prime}$ & $78^{\circ} 50.4^{\prime}$ & 3749 & $11^{\circ} 46.7^{\prime}$ & $78^{\circ} 50.4^{\prime}$ & 3749 \\
\hline 7706 & DR54 & $9^{\circ} 03.7^{\prime}$ & $79^{\circ} 56.2^{\prime}$ & 502 & $9^{\circ} 04.4^{\prime}$ & $79^{\circ} 55.1^{\prime}$ & 375 \\
\hline 7706 & DR59 & $8^{\circ} 03.2^{\prime}$ & $80^{\circ} 22.9^{\prime}$ & 430 & $8^{\circ} 03.2^{\prime}$ & $80^{\circ} 22.9^{\prime}$ & 430 \\
\hline 8506 & DR3 & $11^{\circ} 28.82^{\prime}$ & $78^{\circ} 37.74^{\prime}$ & 1943 & $11^{\circ} 28.00^{\prime}$ & $78^{\circ} 37.63^{\prime}$ & 1915 \\
\hline 8506 & DR4 & $11^{\circ} 28.67^{\prime}$ & $78^{\circ} 36.68^{\prime}$ & 1905 & $11^{\circ} 27.82^{\prime}$ & $78^{\circ} 34.78^{\prime}$ & 1827 \\
\hline 8506 & DR5 & $11^{\circ} 47.06^{\prime}$ & $77^{\circ} 56.35^{\prime}$ & 512 & $11^{\circ} 46.43^{\prime}$ & $77^{\circ} 56.57^{\prime}$ & 355 \\
\hline 8506 & DR6 & \multicolumn{2}{|c|}{ (Lost Dredge) } & & & & \\
\hline 8506 & DR7 & $11^{\circ} 47.94^{\prime}$ & $77^{\circ} 54.23^{\prime}$ & 450 & $11^{\circ} 48.01^{\prime}$ & $77^{\circ} 53.33^{\prime}$ & 305 \\
\hline 8506 & DR9 & $11^{\circ} 16.23^{\prime}$ & $77^{\circ} 35.96^{\prime}$ & 2025 & $11^{\circ} 14.45^{\prime}$ & $78^{\circ} 34.90^{\prime}$ & 1896 \\
\hline 8506 & DR11 & $11^{\circ} 05.37^{\prime}$ & $78^{\circ} 47.67^{\prime}$ & 2130 & $11^{\circ} 05.94^{\prime}$ & $78^{\circ} 44.88^{\prime}$ & 1992 \\
\hline 8506 & DR12 & $11^{\circ} 09.79^{\prime}$ & $78^{\circ} 58.06^{\prime}$ & 2775 & $11^{\circ} 07.49^{\prime}$ & $78^{\circ} 56.66^{\prime}$ & 2575 \\
\hline 8506 & DR14 & \multicolumn{2}{|c|}{ (No recovery) } & & & & \\
\hline 8506 & DR15 & $11^{\circ} 30.10^{\prime}$ & $78^{\circ} 55.11^{\prime}$ & 3810 & $11^{\circ} 28.83^{\prime}$ & $78^{\circ} 52.08^{\prime}$ & 3450 \\
\hline 8506 & DR16 & $11^{\circ} 28.91^{\prime}$ & $78^{\circ} 54.51^{\prime}$ & 3355 & $11^{\circ} 27.31^{\prime}$ & $78^{\circ} 53.76^{\prime}$ & 3015 \\
\hline 8506 & DR17 & $11^{\circ} 27.78^{\prime}$ & $79^{\circ} 11.04^{\prime}$ & 4595 & $11^{\circ} 24.82^{\prime}$ & $79^{\circ} 10.01^{\prime}$ & 4063 \\
\hline 8506 & DR18 & $11^{\circ} 16.90^{\prime}$ & $78^{\circ} 53.51^{\prime}$ & 2840 & $11^{\circ} 15.97^{\prime}$ & $78^{\circ} 50.86^{\prime}$ & 2575 \\
\hline 8506 & DR21 & \multirow{2}{*}{\multicolumn{2}{|c|}{$\begin{array}{l}\text { (No samples) } \\
\text { (No samples) }\end{array}$}} & & & & \\
\hline 8506 & DR22 & & & & & & \\
\hline 8506 & DR25 & $9^{\circ} 35.33^{\prime}$ & $80^{\circ} 11.26^{\prime}$ & 3940 & $9^{\circ} 34.64^{\prime}$ & $80^{\circ} 06.94^{\prime}$ & 3355 \\
\hline 8506 & DR26 & $9^{\circ} 29.94^{\prime}$ & $80^{\circ} 13.83^{\prime}$ & 3960 & $9^{\circ} 28.64^{\prime}$ & $80^{\circ} 09.82^{\prime}$ & 3450 \\
\hline 8506 & DR27 & $9^{\circ} 31.42^{\prime}$ & $80^{\circ} 06.52^{\prime}$ & 3110 & $9^{\circ} 27.91^{\prime}$ & $80^{\circ} 02.68^{\prime}$ & 2535 \\
\hline 8506 & DR28 & $9^{\circ} 30.40^{\prime}$ & $80^{\circ} 06.92^{\prime}$ & 3075 & $9^{\circ} 26.93^{\prime}$ & $80^{\circ} 05.84^{\prime}$ & 2780 \\
\hline 8506 & DR30 & $9^{\circ} 30.45^{\prime}$ & $80^{\circ} 23.24^{\prime}$ & 5440 & $9^{\circ} 30.10^{\prime}$ & $80^{\circ} 20.24^{\prime}$ & 4385 \\
\hline 8506 & DR31 & $9^{\circ} 06.59^{\prime}$ & $80^{\circ} 36.35^{\prime}$ & 5175 & $9^{\circ} 05.63^{\prime}$ & $80^{\circ} 33.80^{\prime}$ & 4770 \\
\hline 8506 & DR32 & $9^{\circ} 04.80^{\prime}$ & $80^{\circ} 27.26^{\prime}$ & 4285 & $9^{\circ} 01.51^{\prime}$ & $80^{\circ} 24.46^{\prime}$ & 3095 \\
\hline 8506 & DR34 & $9^{\circ} 11.12^{\prime}$ & $80^{\circ} 00.80^{\prime}$ & 983 & $9^{\circ} 10.72^{\prime}$ & $79^{\circ} 58.27^{\prime}$ & 652 \\
\hline 8506 & DR35 & $9^{\circ} 01.05^{\prime}$ & $80^{\circ} 04.48^{\prime}$ & 1190 & $8^{\circ} 59.86^{\prime}$ & $80^{\circ} 02.82^{\prime}$ & 930 \\
\hline 8506 & DR36 & $8^{\circ} 47.04^{\prime}$ & $80^{\circ} 06.43^{\prime}$ & 1038 & $8^{\circ} 46.80^{\prime}$ & $80^{\circ} 03.02^{\prime}$ & 755 \\
\hline
\end{tabular}

Note: DR $=$ dredge.

Table 2. Location of core samples collected during the Moana Wave cruise 8506 along the central Peru Continental Margin.

\begin{tabular}{|c|c|c|c|c|}
\hline Cruise & Sample/Core & $\begin{array}{l}\text { Latitude } \\
\text { (S) }\end{array}$ & $\begin{array}{l}\text { Longitude } \\
\text { (W) }\end{array}$ & $\begin{array}{c}\text { Water } \\
\text { depth } \\
\text { (m) }\end{array}$ \\
\hline 8506 & K1 & $11^{\circ} 03.54^{\prime}$ & $77^{\circ} 52.67^{\prime}$ & 125 \\
\hline 8506 & $\mathrm{~K} 2$ & $11^{\circ} 07.77^{\prime}$ & $78^{\circ} 06.54^{\prime}$ & 300 \\
\hline 8506 & $\mathrm{RC} 8$ & $11^{\circ} 48.65^{\prime}$ & $77^{\circ} 53.08^{\prime}$ & 318 \\
\hline 8506 & G10 & $11^{\circ} 18.04^{\prime}$ & $78^{\circ} 37.44^{\prime}$ & 2210 \\
\hline 8506 & G13 & $11^{\circ} 24.66^{\prime}$ & $78^{\circ} 45.47^{\prime}$ & 2495 \\
\hline 8506 & RC19 & (No core & & \\
\hline 8506 & G20 & $11^{\circ} 08.87^{\prime}$ & $79^{\circ} 15.35^{\prime}$ & 3705 \\
\hline 8506 & $\mathrm{~K} 23$ & (No core & & \\
\hline 8506 & K24 & (No core & & \\
\hline 8506 & G29 & $9^{\circ} 24.71^{\prime}$ & $80^{\circ} 07.34^{\prime}$ & 2590 \\
\hline 8506 & RC33 & $8^{\circ} 59.11^{\prime}$ & $80^{\circ} 17.75^{\prime}$ & 2170 \\
\hline 8506 & RC37 & $8^{\circ} 47.03^{\prime}$ & $80^{\circ} 04.97^{\prime}$ & 885 \\
\hline 8506 & RC38 & $9^{\circ} 20.08^{\prime}$ & $79^{\circ} 51.87^{\prime}$ & 1215 \\
\hline 8506 & K39 & $8^{\circ} 55.06^{\prime}$ & $79^{\circ} 18.92^{\prime}$ & 100 \\
\hline 8506 & K40 & (No core) & & \\
\hline
\end{tabular}

$\mathrm{K}=$ kasten; $\mathrm{RC}=$ rock core $\mathrm{G}=$ gravity core.

from the central Peru forearc. However, similar lithologies were found in the Eocene and Miocene sections of the industry drill holes in the Trujillo Basin (Fig. 3).

A tectonized mudstone from Site DR-25 (Sample 8506-25-49) exhibits a well-defined cleavage or fissility and pressure shadows around foraminifer grains; it contains a middle Eocene radiolarian assemblage and also appropriate benthic and planktonic foraminifers for this age (see Appendix A). The benthic fora- minifer assemblage of Sample 8506-25-49 closely resembles that of the Chira Shale, considered to be an outer-shelf/upper-slope deposit of late Eocene age where exposed in the Talara Basin of northwest Peru. Chira equivalents are also present in the base of the Delfin borehole, where Eocene strata directly overlie continental metamorphic basement (Fig. 3). At least $1300 \mathrm{~m}$ of subsidence since middle Miocene time (12-13 m.y.) is indicated by the benthic foraminer assemblage in a younger fossiliferous sample from the same dredge (Table 3, Sample 8506-25-04), at a minimum subsidence rate of $100 \mathrm{~m} / \mathrm{m}$.y. Although no net vertical movement can be documented from middle Eocene to middle Miocene time at this site (i.e. comparable paleodepth ranges for Samples 25-49 and 25-04), the specifics of the vertical tectonic history between 13 and $43 \mathrm{Ma}$ are difficult to reconstruct, given the scarce data and the possibility that the Eocene and Miocene strata may be superposed across one or more unconformable surfaces.

Three living, giant white clams of the genus Calyptogena were also dredged from the cross-margin structure near the transition between the Trujillo and Lima basins at Site DR-25 (Fig. 2A). Based on the recent discovery of such clams in a series of United States-sponsored Alvin submersible dives on the Oregon margin (Kulm et al., 1986) and France- and Japan-sponsored Nautile submersible dives in the Nankai Trough and Japan and Kuril trenches (Boulegue et al., 1986), these clams are supported by chemosynthetic metabolism, whereby symbiotic microbes use hydrogen sulfide and/or methane in pore fluids being expelled from convergent margins. Pore-fluid expulsion results from dewatering of accreted sediments along the Oregon and western Pacific margins. However, the accretionary prism along the central Peru margin is quite thin and restricted to the lowermost 

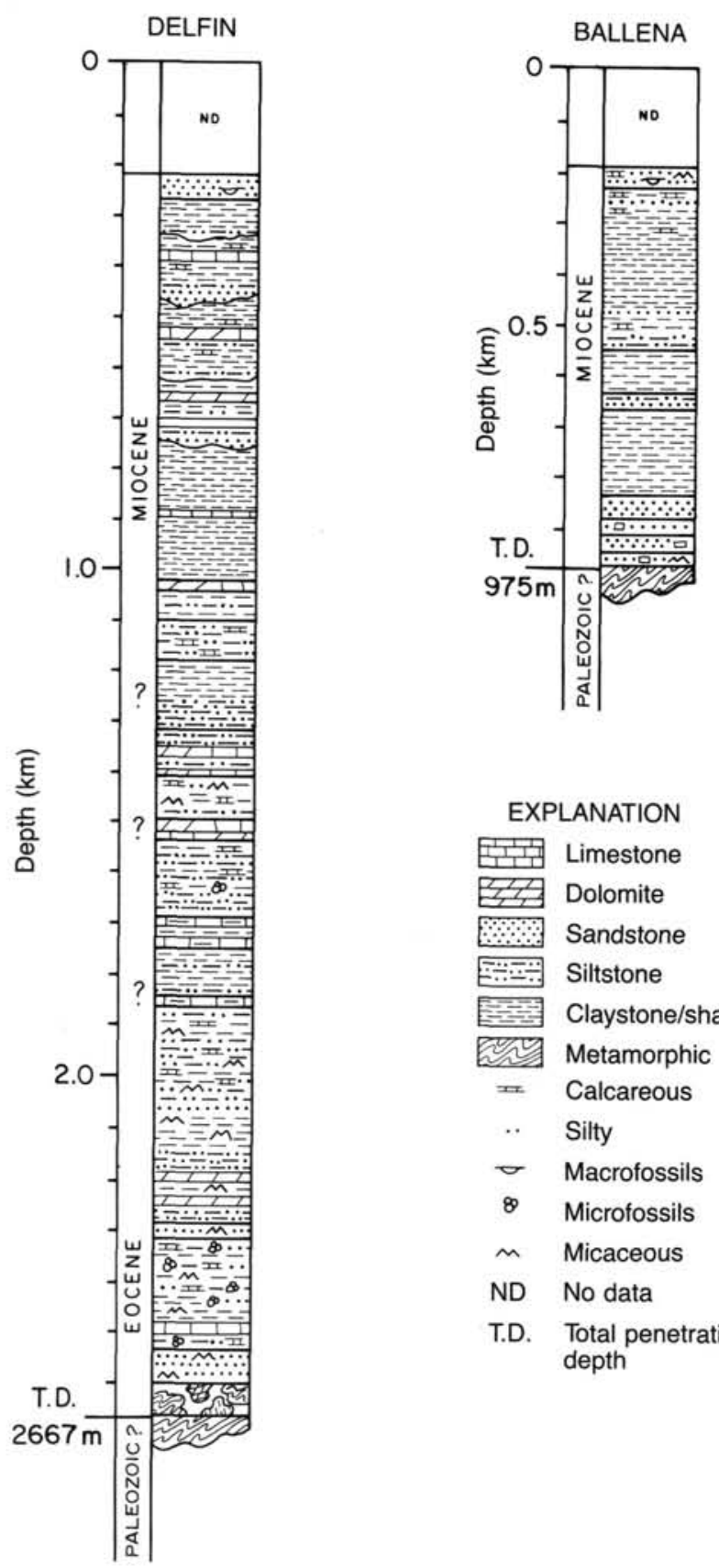

\begin{tabular}{|c|c|}
\hline \multicolumn{2}{|c|}{ EXPLANATION } \\
\hline 医四 & Limestone \\
\hline 色象 & Dolomite \\
\hline W & Sandstone \\
\hline 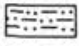 & Siltstone \\
\hline 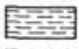 & Claystone/shale \\
\hline 完至 & Metamorphic \\
\hline$\pi$ & Calcareous \\
\hline . & Silty \\
\hline$\sigma$ & Macrofossils \\
\hline 89 & Microfossils \\
\hline n & Micaceous \\
\hline ND & No data \\
\hline T.D. & $\begin{array}{l}\text { Total penetration } \\
\text { depth }\end{array}$ \\
\hline
\end{tabular}

Figure 3. Industry drill holes of the central Peru forearc near $9^{\circ} \mathrm{S}$ latitude. See Figure $2 \mathrm{~A}$ for location. The Ballena well lies over the outershelf high, a horstlike basement ridge, and the Delfin well was drilled on the landward flank of Trujillo Basin. Stratigraphic columns are from Kulm et al. (1985), with biostratigraphic ages modified according to Schrader and Cruzado (pers. comm., 1986). If present, the top of the Eocene and the extent of Oligocene strata are not well defined.

slope; Site DR-25 is apparently situated on a continental foundation landward of the accretionary zone (Moore and Taylor, this volume). Possible fluid sources for Calyptogena sp. in the Peru forearc include the lower strata of the Yaquina Basin, the fractured metamorphic massif that makes up the continental block, or subducted oceanic sediments of the Nazca Plate. The Mendana Fracture Zone, which intersects the Peru Trench near $10^{\circ} \mathrm{S}$ and is believed to be spreading symmetrically about its axis (Fig. 2A; Warsi et al., 1983; Pautot et al., 1986), may exert some influence on the transverse structure crossing the overriding fore- arc. At this time, we can only speculate about the source of the fluids.

\section{LIMA BASIN SURVEY AREA $\left(11.5^{\circ} \mathrm{S}\right)$}

Large areas of the Lima Basin exhibit rock outcrops in the SeaMARC-II mosaic (Hussong et al., this volume) and in single and multichannel seismic records (Moore and Taylor, this volume; Ballesteros et al., this volume). Outcrops on the landward and seaward flanks of the basin were dredged successfully (Fig. 2). Additional dredges were recovered from a midslope terrace overlying fractured continental basement (Sites DR-15 and -16 ), and from the accretionary complex below the trench-slope break of the lowermost slope (Site DR-17). As in previous studies of the area (Kulm et al., 1981), pervasively cemented carbonates (dolomicrite, lime-micrite, and calcareous mudstone) constituted the overwhelming bulk of recovered lithologies. However, based on low-interval seismic velocities and analogies with onshore exposures of similar, poorly oxygenated environments (e.g., Monterey Formation in California), the dominant lithology of the basin is believed to be organic-rich mudstone. Apparently, the cemented carbonates form resistant outcrops on the seafloor that are preferentially dredged.

A microfossil study of Lima Basin rocks showed that sediments in DR-8506-12 (Fig. 2) contained benthic foraminifer assemblages of late Miocene to Pliocene age (6-3 Ma; Tables 1 and 3; Appendix A). The fauna originally lived in water depths of $150-500 \mathrm{~m}$, but were dredged from outcrops on the seaward flank of the Lima Basin at a water depth of 2575 to $2775 \mathrm{~m}$. Assuming that the benthic fauna were not reworked downslope but were deposited in situ (see "Data Acquisition and Methods" section, this chapter), the amount of subsidence at this location should range from 2075 to $2625 \mathrm{~m}$, and the time-averaged subsidence rate should range from $345-875 \mathrm{~m} / \mathrm{m}$.y. In an earlier study (Kulm et al., 1981), about $1100 \mathrm{~m}$ of subsidence since late Miocene to Pliocene time was calculated at a shallower dredge site along-strike in the basin (Fig. 2, Site DR-46), corresponding to a minimum subsidence rate of $275 \mathrm{~m} / \mathrm{m}$.y. during the same interval of time. In still shallower water (837-1201 m), the subsidence rate was calculated at $500 \mathrm{~m} / \mathrm{m}$.y. during the Pleistocene. These data document at least $2 \mathrm{~km}$ of subsidence of the metamorphic continental block beneath the seaward flank of the Lima Basin during the late Neogene (since $6 \mathrm{Ma}$ ).

Farther seaward on the uppermost part of what is believed to be the accretionary complex, DR-17 recovered microbrecciated dolomicrite, fractured mudstone, and calcareous mudstone (Fig. 2). Multiple episodes of fracturing, granulation, and cementation were observed in the microbreccias; brittle disintegration is so pervasive that matrix blocks are reduced to millimetersize. Benthic foraminifers contained in a late Miocene to Pliocene (6-3 Ma) calcareous mudstone (Sample 8506-17-04) indicate a minimum subsidence of $3900 \mathrm{~m}$. The benthic assemblage of a fractured mudstone in contact with cemented microbreccia (Sample 8506-17-06) indicates a similar amount of subsidence during approximately the same period of time (Table 3, Appendix A). Strata transferred from the subducting oceanic plate to the overriding continental plate during the process of sediment accretion should exhibit a deep water, abyssal fauna and a history of uplift. The benthic foraminifer assemblages of Site DR-17 may be derived from deformed forearc basin deposits, rather than sediments scraped off from the trench and oceanic plates.

\section{LITHOLOGIES OF THE PERU MARGIN}

\section{Metamorphic Basement Lithologies}

Gneiss and schist containing bands of coarse-grained quartz and feldspar and alternating with medium- to fine-grained biotite, muscovite, quartz, and feldspar were dredged from the USR 


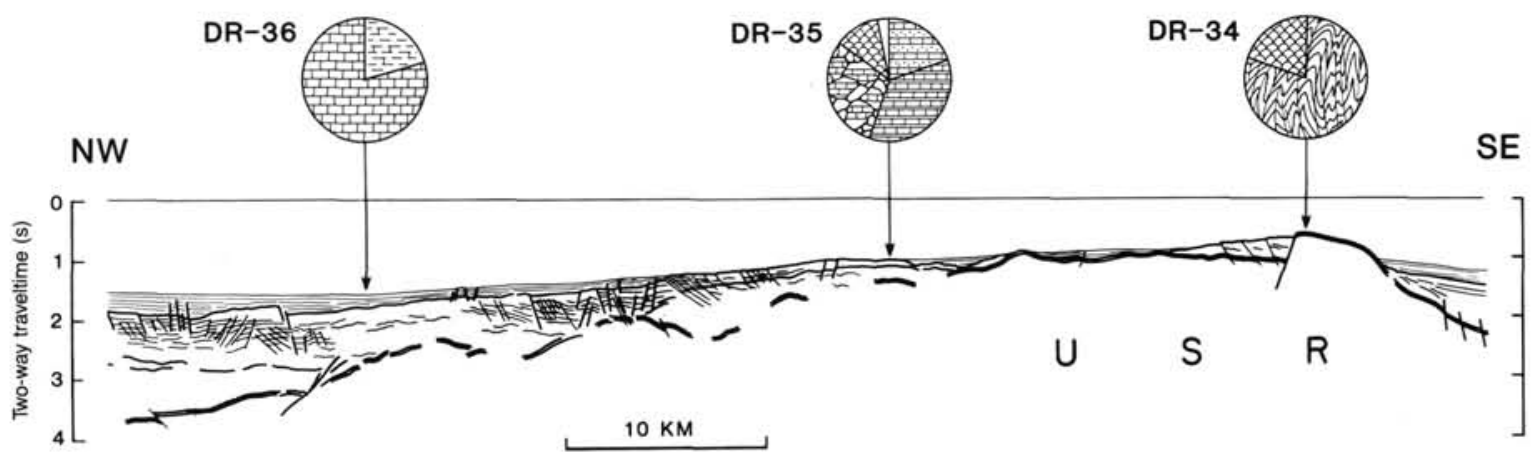

Figure 4. Line interpretation of MCS profile trending parallel to strike along the upper-slope ridge at $9^{\circ} \mathrm{S}$ latitude. (Line 1900 of Thornburg, 1985). See Figure $2 A$ for location. Lithologies of DR-34, -35, and -36 are projected onto the profile (legend as in Fig. 2). Site DR-34 sampled metamorphic basement exposed at the seafloor, Site DR-35 sampled deformed (brecciated) basin strata cropping out against the basement structure (Note: metamorphic fragments and the barnacle-oyster conglomerate of Fig. 5 make up the unlabeled few percentages of the pie diagram), and Site DR-36 sampled young, undeformed strata, including friable mudstones and incipient diagenetic micrites.

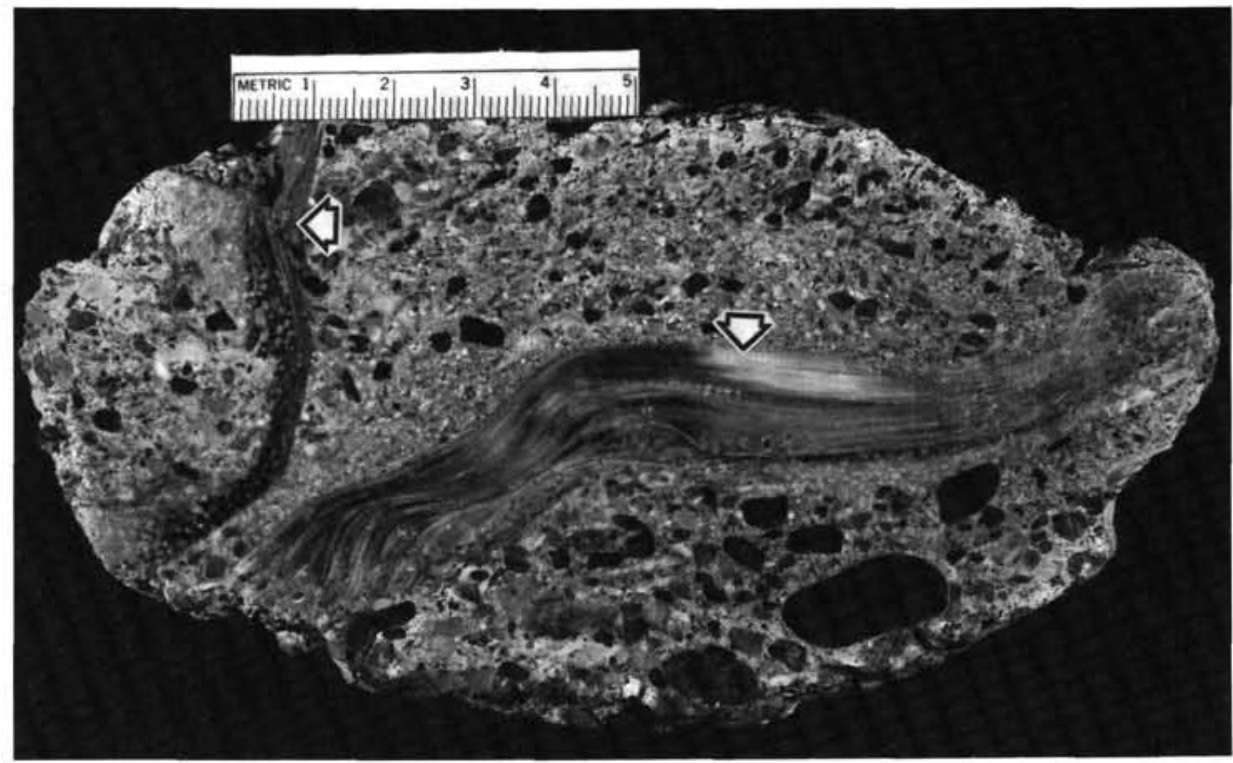

Figure 5. Polished slab of barnacle-oyster conglomerate recovered in DR-35 on the upper-slope ridge. The framework is largely metamorphic (schist) pebbles and barnacle hash. Articulated oyster valves (arrows) indicate minimal transport of the organism from the growth site. Components suggest deposition close to sea level, with subsequent subsidence to present outcrop depths of 930 to $1190 \mathrm{~m}$.

Table 3. Analyses of benthic foraminifers from the Peru margin at about $9^{\circ} \mathrm{S}$ and $11^{\circ} \mathrm{S}$.

\begin{tabular}{lccl}
\hline & $\begin{array}{c}\text { Present } \\
\text { water depth } \\
(\mathrm{m})\end{array}$ & $\begin{array}{c}\text { Depositional } \\
\text { water depth } \\
(\mathrm{m})\end{array}$ & \multicolumn{1}{c}{$\begin{array}{c}\text { Age } \\
(\text { Ma) }\end{array}$} \\
\hline $8506-12-22$ & $2575-2775$ & $150-500$ & late Miocene-Pliocene (6-3) \\
$8506-12-26$ & $2575-2775$ & $150-500$ & late Miocene-Pliocene (6-3) \\
$8506-17-04$ & $4063-4595$ & $50-150$ & late Miocene-Pliocene (6-3) \\
$8506-17-06$ & $4063-4595$ & $150-500$ & late Miocene-Quaternary \\
$8506-25-04$ & $3355-3940$ & $500-2000$ & middle Miocene ( 12-13) \\
$8506-25-49$ & $3355-3940$ & $150-2000$ & middle Eocene (46-43) \\
$8506-30-06$ & $4385-5440$ & $>4000$ & early middle Miocene (13.5-12) \\
$8506-32-02$ & $3312-4285$ & $>4000$ & late Pliocene (3-2) \\
$8506-35-08$ & $930-1190$ & $500-1500$ & late Miocene-Pliocene (6-2) \\
$8506-35-11$ & $930-1190$ & $500-1500$ & late Miocene-Pliocene (6-2) \\
\hline
\end{tabular}

Note: Paleobathymetry of benthic foraminifer species according to Ingle (1980). See Appendix A for detailed description of taxonomy and paleodepth information. at Sites DR-34 and 35 (Figs. 2 and 4; Appendix B). The textures, fabrics, and mineral assemblages of these rocks suggest intermediate-grade regional metamorphism within the amphibolite facies. The presence of andalusite in similar rocks recovered from the basement of the Ballena drill hole (Fig. 3; Appendix B) is consistent with amphibolite facies metamorphism. The presence of muscovite and plagioclase with well-developed twinning indicates that the regional granulite facies was not achieved during metamorphism. Chlorite overgrowths on biotite grains may have been produced by a retrograde event to the lower greenschist facies. Well-developed radiation halos surround zircon inclusions within biotite grains. The metamorphic lithologies are comparable to rocks of Paleozoic or Precambrian age exposed in the Coast Range onshore.

A lower grade of metamorphism affects the basement rocks, primarily slates and metapelites, recovered from the mid- to lower slope at Sites DR-25 and 30 (Fig. 2, Appendix B). These rocks are fine-grained to very fine-grained, but often display in- 
cipient segregation and alignment of mineral phases, which include quartz, feldspar, muscovite, biotite, and chlorite. Sample 8506-25-47A shows well-developed foliation, and sample 850630-2B displays an unusual convoluted shear fabric that may result from deformation along the leading edge of the continental block or within an accretionary complex. The metamorphic rocks of DR-30 are not unambiguously continental in affinity, but associated conglomerates contain rounded quartzite and andesite pebbles in sparry calcite cement. These low-grade metamorphics have the aspect of late Paleozoic rocks onshore, although we cannot exclude the possibility that altered Mesozoic or even Tertiary sediments are present.

\section{Clastic Rocks}

Aside from mudstones and calcareous mudstones, the recovery of clastic lithologies was confined to the northern survey area, centered at a latitude of $9^{\circ} \mathrm{S}$. Conglomerates with rounded, centimeter-sized, metamorphic pebbles were dredged from Sites DR-30 and 35 in water depths down to $5440 \mathrm{~m}$ (Fig. 2). Fragments of metamorphic material were also dredged at both sites. These conglomerates may have formed as a basal lag deposit directly overlying the metamorphic basement of the Peru continental block. Similar metamorphic rubble was recovered at the basement unconformity beneath strata of Eocene age, at $2.6 \mathrm{~km}$ subsurface in the Delfin drill hole and in a water depth of $119 \mathrm{~m}$ in the Trujillo Basin (Fig. 3; Kulm et al., 1985). A conglomerate from DR-35 contains an articulated oyster shell and barnacle debris, components that certify a nearshore, shallow-water origin for the deposit (Fig. 5). Substantial tectonic subsidence is clearly implied if the conglomerate was dredged from local outcrops on the upper slope at water depths of 900 to $1200 \mathrm{~m}$.

Siliciclastic sandstones were restricted to Sites DR-25 and 30 in the northern survey area. DR-25 yielded the greatest volume of clastic material (Fig. 2). Lithologies include medium- to coarse-grained massive sandstone, and graded sands with turbidite or traction structures. Some sands are very micaceous and may be derived from schistose parent rocks. Many sands are cemented by calcium carbonate and may provide bedding-parallel migration pathways for subsurface fluids. The sandstones of DR-25 most closely resemble the Eocene strata of the Delfin industry hole from the Trujillo Basin (Fig. 3). A radiolarian-foraminifer assemblage in a scaly mudstone from DR-25 (Sample 49) confirms a middle Eocene age (Table 3). Aside from the metamorphic basement rocks, these clastics probably represent the oldest lithologies recovered from the Peru margin during the site-survey sampling program. The Eocene lithologies associated with DR-25 are apparently exposed along a transverse SeaMARC structure near the interface between the Lima and TrujilloYaquina basins at a latitude of $9.5^{\circ} \mathrm{S}$ (Fig. 2; Hussong et al., this volume). The structure may constitute a major tear fault or rupture zone, as it is positioned opposite the Mendaña and Vera fracture zones on the Nazca Plate (see Pautot et al., 1986).

Calcarenites, or clastic accumulations of sand- and pebblesized carbonate detritus, were specific to DR-35 on the seaward flank of the Trujillo Basin. These calcarenites probably formed as a biogenic lag deposit that was winnowed from fossiliferous mud on the upper slope, along that part of the margin where contour currents reach their highest velocities (Smith, 1983; Kulm et al., 1984).

\section{Mudstones}

Mudstones of various origins and degrees of induration are common along the Peru margin. More indurated varieties are associated with the siliciclastic sands and turbidites of DR-25, where at least one sample is Eocene in age. The most indurated mudstones are cemented by carbonate minerals; many exhibit fracturing from tectonism or dewatering that enhances permeability and facilitates cementation.

\section{Organic-Rich Mudstones}

Most mudstones from the Peru margin constitute an organicrich sedimentary facies derived from an upwelling environment. The modern upwelling facies accumulates on the outer continental shelf and upper slope, seaward of high-productivity surface waters on the inner shelf. In its purest development, along the landward flank of the Lima Basin at a water depth of 50 to $680 \mathrm{~m}$, the upwelling facies is anomalously rich in organic matter ( $>5 \%$ organic carbon), biogenic debris (diatoms, foraminifers, and fish debris), and fine-grained sediment ( $>60 \%$ clay) (Krissek et al., 1980; Scheidegger and Krissek, 1983; Reimers and Suess, 1983; and Suess et al., 1987). Because the Lima Basin has undergone rapid subsidence since late Miocene time, the older organic-rich mudstones and their diagenetic equivalents were recovered from substantially greater water depths than those in which the modern facies is presently accumulating.

The high influx of organic carbon to the depositional surface beneath upwelling zones exhausts the oxygen content of the bottom waters through aerobic oxidation. This allows a significant fraction of the organic-carbon flux to be preserved and buried in the sediment. Because anoxic environments are unfavorable to benthic colonization, bioturbation is suppressed, and temporal variations in biogenic or terrigenous influx are often preserved as fine laminations. Some laminations are formed by thin residual lag deposits of microfossils, suggesting periodic increases in current strength that winnow the mud and temporarily increase the oxygen content of the bottom waters.

\section{Micrites, Dolomicrites, and Calcareous Mudstones}

The most prominent lithologies in terms of total volume of dredged material are aphanitic limestones and dolomites (micrites and dolomicrites), almost invariably present in dredge hauls extending hundreds of kilometers along the strike of the continental margin and in water depths ranging from 200 to $>5000 \mathrm{~m}$ (Fig. 2). These dense, cryptocrystalline carbonates are typically dark gray to dark brown, sometimes finely laminated, and contain abundant biogenic detritus typical of the high productivity associated with upwelling (Kulm et al., 1984). The carbonates form by the pervasive cementation of upwelling sediments in the subsurface, diagenetic environment - a process that transforms an initial organic-rich mud into an authigenic carbonate (i.e., the delicate microfossils, fibrous organic matter, and high sedimentation rates impart a high primary porosity to the upwelling muds that is subsequently infilled by carbonate cement).

During the transformation from porous organic mud to dense carbonate, organic carbon is consumed by oxidation to supply carbonate anions to the cementing fluids. Calcareous mudstones represent an intermediate stage in the diagenetic process at which the sediment retains some amount of organic matter and primary porosity, but achieves some degree of induration as a result of incipient cementation. The best examples of partially lithified calcareous mudstones and laminated calcareous mudstones were recovered from the walls of a submarine canyon, which cuts the upper few hundred meters of strata in the Lima Basin (Fig. 2; DR-5, -7, and DRAG; DRAG is Pleistocene in age, according to Kulm et al., 1981). Older strata, traced along seismic reflectors to subsurface depths of $1000 \mathrm{~m}$ or more in the Lima Basin's depocenter, crop out on the seaward flank of the upperslope ridge. Dredges from this structure yielded vast amounts of dolomicrite, laminated dolomicrite, and phosphorite-veneered dolomicrite, with only minor amounts of calcareous mudstone (DR-3, -4, -9, -11, and -46; DR-46 is late Miocene-Pliocene in age). These data suggest that carbonate cementation becomes more thorough and pervasive with increasing age and depth in the Lima Basin, and that perhaps the cemented units become thicker and constitute a greater proportion of the total stratigraphy as well. 


\section{Mineralogy}

The composition of the diagenetic carbonates varies from calcite having 2 to $12 \mathrm{~mol} \% \mathrm{MgCO}_{3}$ to dolomite having 46 to 53 mol\% $\mathrm{MgCO}_{3}$ (Fig. 6, Appendix C). Calcite mineralogies were most abundant in dredges from the Trujillo Basin (DR-35,-36), but were also recovered from the midslope seaward of the Lima Basin (DR-18; Fig. 2). Previous studies showed that dolomites from the Trujillo Basin are rich in calcium, while those from the Lima Basin are more nearly stoichiometric or slightly enriched by magnesium (Kulm et al, 1984). Geochemical reactions involving the biodegradation of organic carbon in the shallow diagenetic environment-reactions that are sensitive to the subsidence and sedimentation rates of the basins, the productivity in the overlying water column, the oxygen content of the bottom waters, and the composition of the precursor sedimentare thought to be responsible for the chemical and mineralogical distinctions between the carbonates of the Lima and Trujillo basins (Suess et al., 1987). Age and burial depth may play an additional role in determining the mineralogy of the carbonate precipitate, since dolomicrites were dredged from younger strata more interior to the Trujillo Basin syncline (DR-54 and -59), while lime micrites were dredged from older strata that crop out on the seaward flank of the upper-slope ridge (DR-35 and -36).

\section{Carbon and Oxygen-Stable Isotopes}

The ${ }^{13} \mathrm{C}$ stable-isotope values range from $-37.3 \%$ to $+17.7 \%$ relative to PDB; (Fig. 6; Appendix C); the variability is produced by isotopic fractionations during organic-matter decomposition. Decay by microbial fermentation yields isotopically heavy $\delta^{13} \mathrm{C}$ values, while decay by sulfate reduction yields light values (Kulm et al., 1984; Suess et al., 1987). The $\delta^{13} \mathrm{C}$ values are correlated with both carbonate mineralogy and geographic position along the continental margin of central Peru. Calcites $(<20 \mathrm{~mol} \% \mathrm{Mg})$ from the Trujillo Basin are the most depleted in ${ }^{13} \mathrm{C}$, calcites from the Lima Basin and calcium-rich dolomites from the Trujillo Basin exhibit intermediate values, and near-stoichiometric or magnesium-rich dolomites from the Lima Basin are most enriched in the heavy carbon isotope (Fig. 6). In both calcite and dolomite mineralogies, the Lima Basin samples yield consistently heavier $\delta^{13} \mathrm{C}$ values compared with Trujillo Basin samples. This is a result of the higher subsidence, sedimentation, and organic-matter accumulation rates of the Lima Basin that favor fermentation processes during diagenesis. Within a given basin, dolomite mineralogies yield consistently heavier $\delta^{13} \mathrm{C}$ values, compared to calcite mineralogies. Carbon13 values from the mid-lower slope in the $11.5^{\circ} \mathrm{S}$ survey area are consistent with those of the more landward Lima Basin. Car-

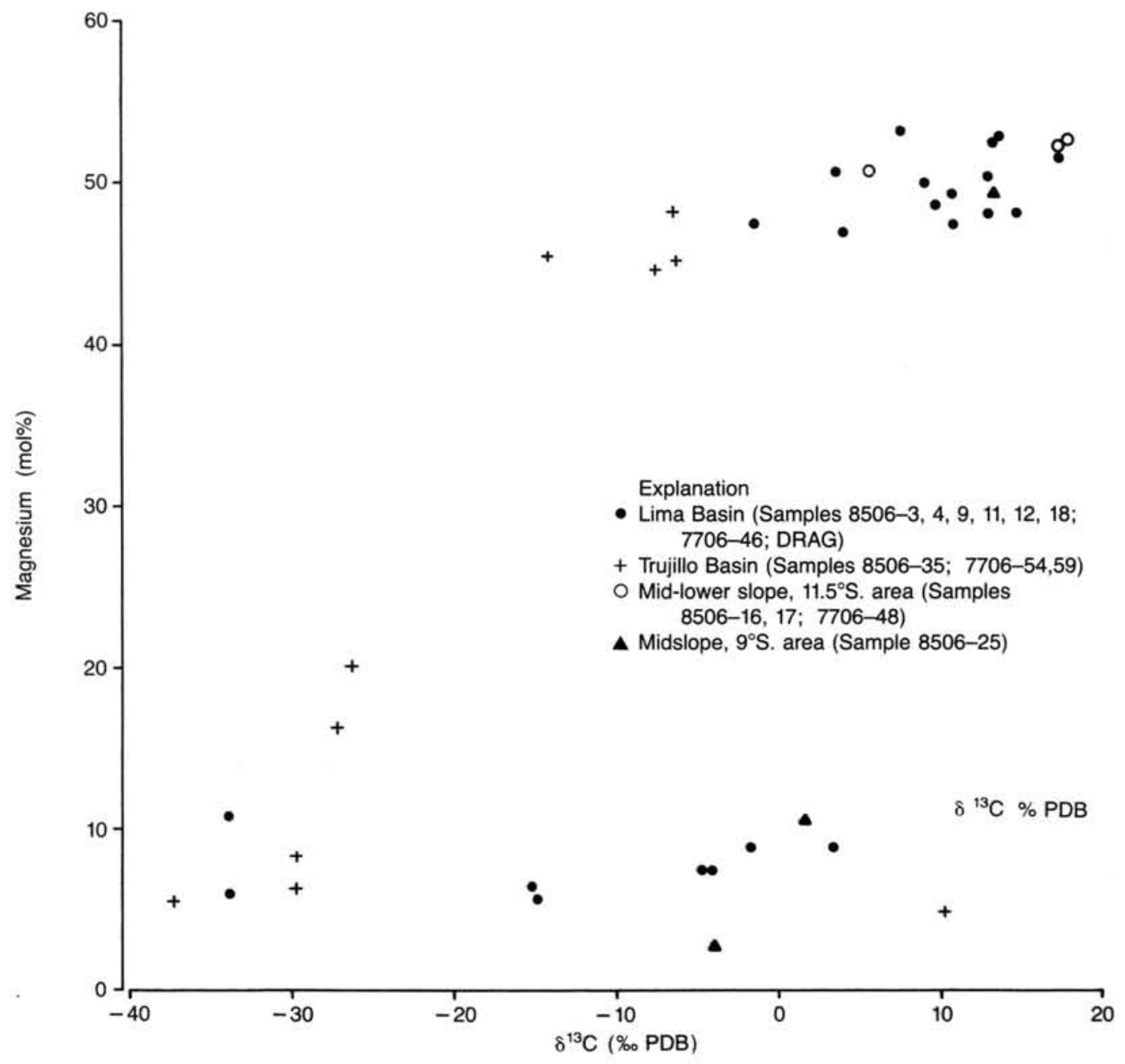

Figure 6. Mineral chemistry (mol\% $\mathrm{Mg}$ ) vs. stable-carbon isotope composition $\left(\delta^{13} \mathrm{C} \%\right.$, PDB) of diagenetic carbonates from the central Peru forearc. Calcites and dolomites are mainly derived from microbially mediated fermentation and sulfate reduction of sedimentary organic matter; few high-Mg calcites (samples with $\delta^{13} \mathrm{C}<-25 \%$ ) are found by methane oxydation. See text for detailed explanation. 
bon- 13 values from the midslope of the $9^{\circ} \mathrm{S}$ survey area are anomalously heavy compared to the Trujillo Basin samples recovered upslope. In general, it appears that diagenetic pore waters that contain $\mathrm{CO}_{3}$ anions with isotopically light carbon are associated with low $\mathrm{Mg} / \mathrm{Ca}$ ratios, and $\mathrm{CO}_{3}$ anions with isotopically heavy carbon are associated with high $\mathrm{Mg} / \mathrm{Ca}$ ratios.

The ${ }^{18} \mathrm{O}$ stable-isotope composition of the majority of carbonate samples ranges from +4.76 to $+7.42 \%$ relative to PDB (Appendix C). While it is clear that many of the carbonates precipitated at low temperatures in the shallow diagenetic environment, it also seems likely that the isotopic composition of the cementing pore fluids deviated positively from that of Standard Mean Ocean Water (SMOW) to produce such pronounced ${ }^{18} \mathrm{O}$ enrichment (i.e., the $\delta^{18} \mathrm{O}$ values are a function of both the temperature of formation and the isotopic composition of the pore fluids). In contrast, a few samples from the northern survey area exhibit unusually low $\delta^{18} \mathrm{O}$ values, specifically calcite cements from DR-25 and -35. The most extreme ${ }^{18} \mathrm{O}$-depleted values of the entire margin were obtained from a calcite-cemented sand and a coarse, fibrous vein cement from DR-25 $(-1.52,-2.31 \%$, respectively). These exceptionally light isotopic compositions indicate that the calcite cements precipitated either from (1) pore fluids of high temperature ascending rapidly from subsurface depths, perhaps along the transverse structure at $9.5^{\circ} \mathrm{S}$, or (2) pore fluids of low salinity, perhaps charged by meteoric waters during subaerial exposure and unconformity formation, followed by substantial subsidence to present water depths.

\section{Other Authigenic Rocks}

Phosphorite nodules, slabs, and crusts-typically black, conglomeratic, and concretionary in aspect - were dredged from both the northern and southern survey areas (Fig. 2). These rocks are most prolific on the upper slope in water depths of 300 to $2000 \mathrm{~m}$ (DR-4, -9, -34, -35, and -59), though deeper occurrences were found (DR-15 and -16 , to $3800 \mathrm{~m}$ ). A phosphorite crust from Site DR-59 contained a Holocene foraminifer assemblage, which implies that such crusts are actively forming in the modern environment on the surface of older lithologies cropping out on the seafloor (Kulm et al., 1981).

Pebbly, carbonate-cemented, glauconitic sands were recovered only from the northern survey area (Fig. 2; DR-25, -54, and -59). The broad shallow continental shelf of north-central Peru (Trujillo region) is apparently more suitable for glauconite formation than that of south-central Peru (Lima region) because (1) the seafloor is more effectively agitated by bottom currents, (2) bottom waters are more oxygenated, and (3) less organic carbon from surface productivity accumulates in the sediment. Deeper occurrences of glauconite (e.g., DR-25) may have initially formed on an outer-shelf/upper-slope platform; however, either the green sands were mobilized and resedimented downslope, or the forearc has subsided since their formation. A few small nodules of chert were present in one dredge from the midto lower slope near $9^{\circ} \mathrm{S}$ (Fig. 2, DR-32).

\section{Tectonized Lithologies}

Some of the more indurated mudstones in the forearc basins were fractured, presumably in response to tectonism or dewatering associated with plate convergence (Fig. 2; DR-7 and -46). Typically, these mudstones are partially cemented by carbonate as a result of enhanced permeability and more vigorous porewater movement through subparallel fracture systems.

Similarly, many of the micrites and dolomicrites were tectonically fractured into angular breccia blocks, and the fracture porosity infilled with aphanitic carbonate cement (Fig. 2; DR-3, $-4,-7,-11,-16,-17,-18,-25,-35,-46,-54$, and -59$)$. The fracture cements incorporate variable amounts of internal sediment, which is apparently contributed by disaggregation of surround- ing, noncemented, muddy lithologies. The breccia blocks are sometimes tightly interlocked along hairline fracture systems, apparently in an incipient state of disaggregation, or they may be floating or suspended in a fracture cement that exceeds the volume of the breccia blocks. Rocks that display evidence of excessive granulation, especially those exhibiting multiple episodes of brecciation/cementation in which matrix blocks are themselves brecciated, are here termed "microbreccias" (Fig. 7). Both compressional and extensional microstructures are evident in hand samples; presumably either style of deformation may produce the observed breccia textures.

In the northern area, the recovery of brecciated carbonates was essentially confined to the Trujillo Basin on the upper continental slope (Fig. 2; DR-35, -54, and -59). Seismic-reflection studies showed that Trujillo Basin strata have suffered pervasive brittle deformation (Thornburg, 1985; Thornburg and Kulm, 1981); thus, it is not surprising that these strata yielded large volumes of tectonized carbonates. In contrast, Lima Basin strata are conformable, broadly synclinal, and only locally cut by extensional faults; much smaller quantities of brecciated rocks were recovered from this basin. The intensity of deformation appears to increase in a seaward direction near $11.5^{\circ} \mathrm{S}$, from the Lima Basin to the trench (Fig. 8). Sample 8506-9-1, from an interior position in the Lima Basin (water depth of 1900-2030 m), contains uncemented, hairline microfaults that displace depositional laminations. Sample 8506-3-19, from the seaward flank of the upper-slope ridge (1920-1940 m) exhibits a single episode of brecciation and cementation. Sample 8506-16-19, situated on a midslope structural ridge $(3020-3360 \mathrm{~m})$, is cut by at least two distinct generations of fracture cement. Finally, Sample 8506$17-10$, from the presumed accretionary complex along the inner trench wall ( $4060-4600 \mathrm{~m})$, constitutes a classic microbreccia, in which tiny blocks of matrix, cement, and granulated material are enclosed in carbonate cement and internal sediment after undergoing multiple episodes of brecciation followed by cementation and fracture healing (see Fig. 7). The trenchward increase in deformation intensity of the brecciated carbonates may reflect the progressive extensional collapse of the continental block from the toe of the forearc toward the hinterland as a result of subduction erosion.

\section{ACKNOWLEDGMENTS}

We thank the crew of the Moana Wave for their valuable assistance during the 8506 cruise and acknowledge the help of Peter Kalk, William Rugh, Marta von Breyman, Sara Culley, and Tom Reed during the collection of the dredge and core samples. We appreciate the efforts of David Davila of Instituto Geológico Minero y Metalurgico (INGEMMET), José Cruzado of Petróleos del Perú (Petro-Peru), and Felix Monke of Instituto Geofisico del Peru (IGP) for their participation in shipboard activities and preliminary sample descriptions. The manuscript benefited from the insightful reviews of Bob Garrison and Roland von Huene. This study was sponsored by the Joint Oceanographic Institutions, Inc. under contract 56-83 to the College of Oceanography, Oregon State University.

\section{REFERENCES}

Boulegue, J., Charlou, J. L., and Jedwab, J., 1986. Fluids from subduction zones off Japan. Eos, Trans. Am. Geophys. Union, 67:1204.

Cushman, J., and Stone B., 1947. An Eocene foraminiferal fauna from the Chira Shale of Peru. Cushman Lab. Foram. Res. Spec. Publ. 20.

Ingle, I. C., 1980. Cushman Foundation Spec. Publ., 19:163-195.

Kleinpell. R., 1980. The Miocene stratigraphy of California revisited. AAPG Studies Geol., 11:1-182.

Krissek, L. A., Scheidegger, K. F., and Kulm, L. D., 1980. Surface sediments of the Peru-Chile continental margin and the Nazca plate: textural and geochemical characteristics and their controls. Geol. Soc. Am. Bull., 91:321-331.

Kulm, L. D., Schrader, H., Resig, J. M., Thornburg, T. M., Masias, A., and Johnson, L., 1981. Late Cenozoic carbonates on the Peru conti- 
nental margin: lithostratigraphy, biostratigraphy, and tectonic history. Geol. Soc. Am. Mem., 154:469-508.

Kulm, L. D., Suess, E., and Thornburg, T. M., 1984. Dolomites in organic-rich muds of the Peru forearc basins: analogue to the Monterey Formation. In Garrison, R. E., Kastner, M., and Zenger, D. H. (Eds.), Dolomites of the Monterey Formation and Other OrganicRich Units. Pacific Section, Soc. Econ. Paleontol. Mineral., 41:2947.

Kulm, L. D., Thornburg, T. M., and Dang, S., 1985. Drill hole stratigraphy, dredge lithologies, and sample locations. In Hussong, D. M., et al. (Eds.), Atlas of the Ocean Margin Drilling Program, Peru Continental Margin, Region VI: Woods Hole, MA (Marine Science International), Sheet 18.

Kulm, L. D., Suess, E., Moore, J. C., Carson, B., Lewis, B. T., Ritger, S. D., Kadko, D. C., Thornburg, T. M., Embley, R. W., Rugh, W. D., Massoth, G. J., Langseth, M. G., Cochrane, G. R., and Scamman, R. L., 1986. Oregon subduction zone: venting, fauna, and carbonates. Science, 231:561-566.

Natland, M., 1940. New genus of foraminifera from the later Tertiary of California. J. Paleontol.; 14:568-571.

Pautot, G., Bourgois, J., Bandy, W., Boinet, T., Chotin, P., Huchon, P., Mercier de Lepinay, B., Monge, F., Monlau, J., Pelletier, B., Sosson, M., and von Huene, R., 1986. Fragmentation de la plaque Nazca a l'Ouest de la fosse du Perou: resultats de la campagne SEAPERC du Jean-Charcot, 1986. C. R. Acad. Sci. Paris, t. 303, Serie II, $18^{\circ} \mathrm{N}, 1651-1656$.

Reimers, C. E., and Suess, E., 1983. Spatial and temporal patterns of organic matter accumulation on the Peru continental margin. In Thiede, J., and Suess, E. (Eds.), Coastal Upwelling: Its Sediment Record, Part B: New York (Plenum Press), 311-346.
Renz, H. H., 1948. Stratigraphy and fauna of the Agua Salada Group, State of Falcón, Venezuela. Geol. Soc. Am. Mem., 32.

Scheidegger, K. F, and Krissek, L. A., 1983. Zooplankton and nekton: natural barriers to the seaward transport of suspended terrigenous particles off Peru. In Suess, E., and Thiede, J. (Eds.), Coastal Upwelling: Its Sediment Record, Part A: New York (Plenum Press), 303-333.

Smith, R. L., 1983. Peru coastal currents during El Niño: 1976 and 1982. Science, 221:1397-1399.

Suess, E., Kulm, L. D., and Killingley, J. S., 1987. Coastal upwelling and a history of organic-rich mudstone deposition off Peru. In Brooks, J., and Fleet, A. (Eds.), Marine Petroleum Source Rocks: London (Blackwell Publishing Ltd.), Geo. Soc. Spec. Publ., 24: 181-197.

Thornburg, T. M., 1985, Seismic stratigraphy of Peru forearc basins. In Hussong, D. M., et al. (Eds.), Atlas of the Ocean Margin Drilling Program, Peru Continental Margin, Region VI: Woods Hole, MA (Marine Science International).

Thornburg, T. M., and Kulm, L. D., 1981. Sedimentary basins of the Peru continental margin: structure, stratigraphy, and Cenozoic tectonics from $6^{\circ} \mathrm{S}$ to $16^{\circ} \mathrm{S}$ latitude. Geol. Soc. Am. Mem., 154:393422.

Warsi, W.E.K., Hilde, T.W.C., and Searle, R. C., 1983. Convergence structures of the Peru Trench between $10^{\circ} \mathrm{S}$ and $14^{\circ} \mathrm{S}$. In Hilde, T.W.C., and Uyeda, S. (Eds.), Convergence and Subduction. Tectonophysics, 99:313-329.

\section{Ms 112A-106}



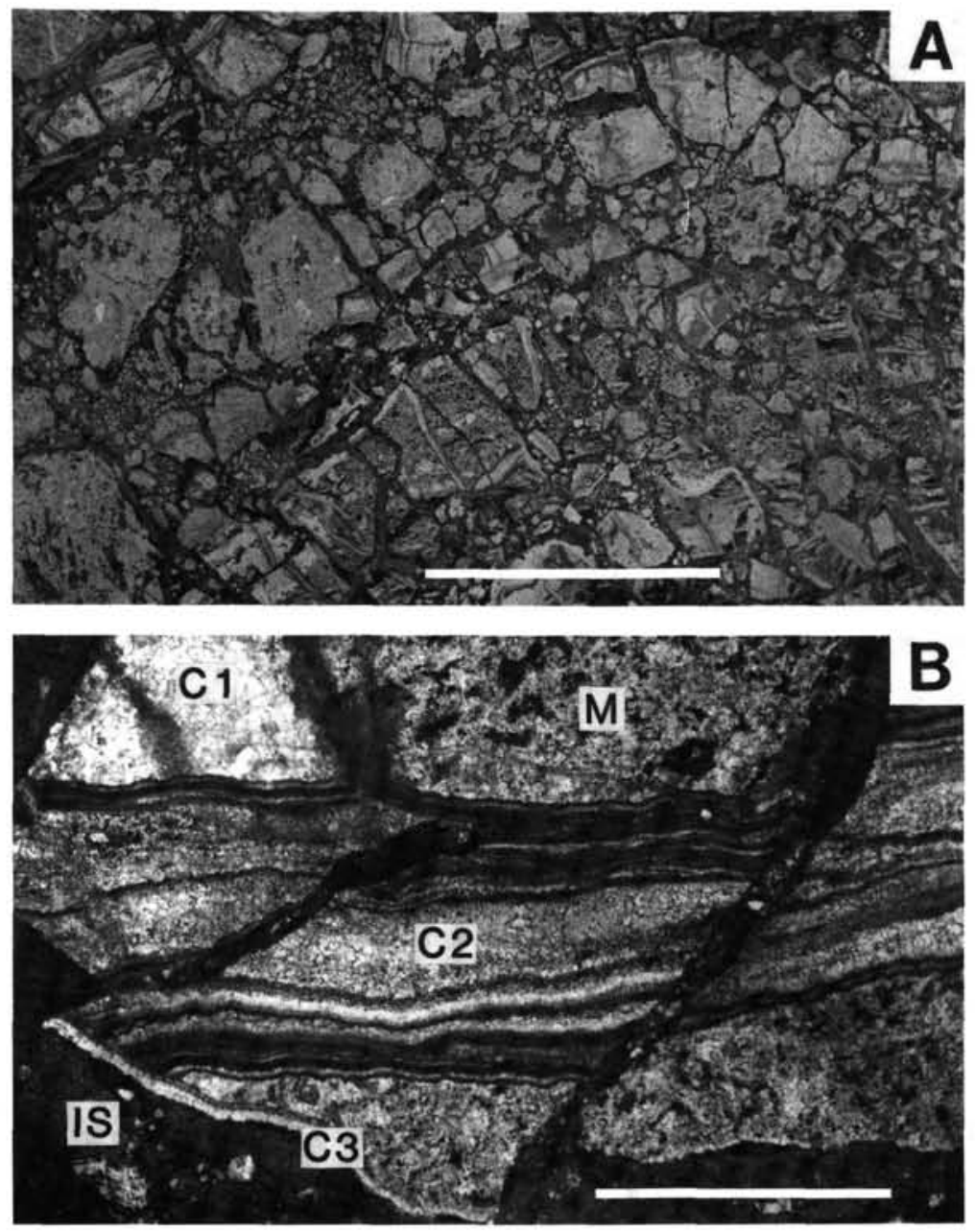

Figure 7. Thin-section photograph $(\mathrm{A}$, scale bar $=1 \mathrm{~cm})$ and photomicrograph $(\mathrm{B}$, scale bar $=1 \mathrm{~mm}$ ) of microbrecciated dolomite from the trench-slope break at $15^{\circ} \mathrm{S}$ (Sample 8506-17-10). Microbreccias exhibit multiple episodes of fracturing, granulation, and cementation. Petrographic relationships establish sequential diagenetic development: fine-grained matrix (M, largely recrystallized) is cut by first-generation, sparry fracture cement $(\mathrm{C} 1)$, second generation, growth-banded cement $(\mathrm{C} 2)$, thirdgeneration, isopachous rim cement (C3), and a final episode of disaggregation followed by internal sedimentation of fracture porosity (IS). 

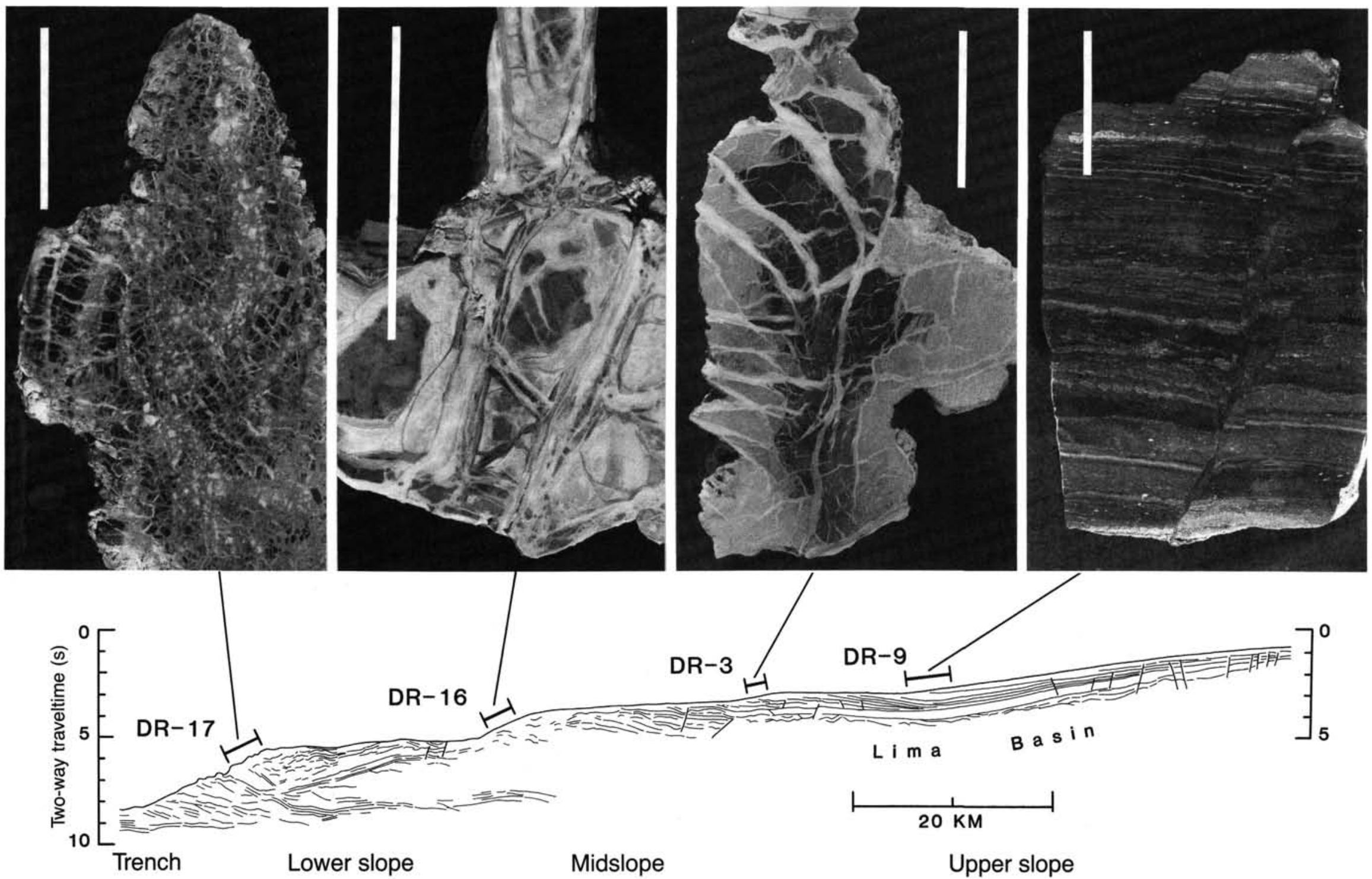

Figure 8. Polished sections of fractured and brecciated carbonates collected across the Lima Basin (Samples 8506-9-1 and 8506-3-19), the midslope basin (Sample 8506-16-19), and accretionary (?) complex (Sample 8506-17-10) of central Peru at $11.5^{\circ} \mathrm{S}$. Seismic interpretation of CDP-1 is from R. von Huene. Dredges and profile are located in Figure $2 \mathrm{~B}$. Scale bar is $5 \mathrm{~cm}$ in all cases. Note seaward increase in deformation intensity and multistage fracturing, evidence for progressive extensional collapse of the continental margin in response to subduction erosion at the toe of the forearc. 


\section{APPENDIX A}

Faunal taxonomy and paleobathymetry of selected mudstone and carbonate lithologies from Peru sites dredged during the Moana Wave cruise 8506

Sample 8506-12-22; present water depth, 2575-2775 m.

Sandy siltstone with a few centric diatoms and with benthic foraminifers, mostly Uvigerina segundoensis $\mathrm{Gr}$. and Buliminella elegantissima.

Estimated age: late Miocene or Pliocene $(\simeq$ Delmontian $=6-3 \mathrm{Ma})$. Estimated water depth: $150-500 \mathrm{~m}$ (upper bathyal), with displaced inner and outer shelf $(<50-150 \mathrm{~m})$ foraminifers.

Benthic foraminifers ( ${ }^{*}$ Delmontian association of Kleinpell, 1938, 1980)

Abundant

Buliminella elegantissima (d'Orbigny) depth $(\mathrm{m})$

0-50

*Uvigerina segundoensis (Cushman and Galliher) Gr.

$150-500$

Common

*Bolivina seminuda humilis Cushman and McCulloch

$150-500$

$150-500$

$50-150$

* Bolivina vaughani Natland

* Bulimina uvigerinaformis doanei (Kleinpell and Tipton)

Valvulineria cf. sinecarina Coryell and Mossman

Rare

Baggina robusta Kleinpell

*Bolivina churchi almgreni Kleinpell and Tipton

Buliminella curta Cushman

Cassidulina cf. oblonga Reuss

Robulus spp.

$150-500$

$50-150$

$50-150$

Sample 8506-12-26; present water depth, 2575-2775 m.

Ashy siltstone with rare radiolarians and diatoms and with benthic foraminifers, mostly Uvigerina segundoensis and Buliminella elegantissima.

Estimated age: late Miocene or Pliocene $(\simeq$ Delmontian $=6-3 \mathrm{Ma})$

Estimated water depth: 150-500 (upper bathyal) with displaced inner and outer shelf $(<50-150 \mathrm{~m})$ foraminifers.

Benthic foraminifers (*Delmontian association of Kleinpell, 1938, 1980)

Abundant

*Uvigerina segundoensis (Cushman and Galliher) Gr.

Water depth $(\mathrm{m})$ $150-500$

Common

Buliminella elegantissima (d'Orbigny)

Few to rare

* Bolivina seminuda humilis Cushman and McCulloch

* Bolivina rankini Kleinpell

${ }^{*}$ Bulimina uvigerinaformis doanei (Kleinpell and Tipton)

Epistominella subperuviani (Cushman)

Valvulineria cf. sinecarina Coryell and Mossman

$150-500$

$150-500$

Sample 8506-17-4; present water depth, 4063-4595 m.

Siltstone with a few radiolarians and poorly preserved benthic foraminifers, mostly Buliminella.

Estimated age: late Miocene or Pliocene

Estimated water depth: 50-150 m (outer shelf).

Benthic foraminifers

Common

Buliminella curta Cushman

Water

depth (m)
Few to rare

Bolivina rankini Kleinpell

$150-500$

Bolivina sinuata praevia Coryell and Mossman

Bolivina vaughani Natland

Bulimina uvigerinaformis doanei (Kleinpell and Tipton)

Cassidella californiensis grandis Cushman and Kleinpell

Epistominella subperuviana (Cushman)

Nonionella sp.

Valvulineria californica Cushman

$150-500$

$150-500$

$150-500$

Sample 8506-17-6; Present water depth, 4063-4595 m.

Siltstone with abundant diatoms, frequent radiolarians, and benthic foraminifers, mostly Buliminella and Bolivina. Foraminifers partly dissolved. No radiolarian indices noted.

Estimated age: ?late Miocene to Quaternary.

Estimated water depth: 150-500 m (upper bathyal)

Benthic foraminifers

Common

Bolvina rankini Kleinpell

Water

depth (m)

$150-500$

Buliminella curta Cushman

$50-150$

Few to rare

Bolivina charapotoensis Cushman and Stevenson

Bolivina vaughani Natland

Bolivina spp.

Cassidulina sp.

Epistominella pacifica (Cushman) $\quad 500-150$

Epistominella subperuviana (Cushman)

$150-500$

Plectofrondicularia $\mathrm{sp}$.

Stilostomella advena (Cushman and Laiming)

$1500-2000$

Uvigerina proboscidea Schwager

1500-2000

Sample 8506-25-04; present water depth, 3355-3940 m.

Glauconitic diatomaceous mudstone with abundant benthic foraminifers and radiolarians-no planktonic foraminifers. Benthic foraminifer assemblage similar to that in Agua Salada Gr. of Venezuela, which appears to be middle Miocene (N11-13, Globorotalia fohsi Zone).

Age: middle Miocene.

Estimated water depth: 500-2000 m (middle bathyal) with displaced outer-shelf species $(50-150 \mathrm{~m})$.

Benthic foraminifers

Abundant

Bulimina alligata Cushman and Laiming

Water

Buliminella curta Cushman

depth (m)

$500-1500$

$50-150$

Spirobolivina $\mathrm{cf}$. directa (Cushman)

Common

Bolivina pseudospissa Kleinpell

$500-1500$

Bolivina tongi Cushman

$50-150$

Bulimina uvigerinaformis Cushman and Kleinpell

$50-150$

Buliminella equadorana Cushman

Nodosaria stainforthi Cushman and Renz

Planulina cf. marialana Hadley

Uvigerina auberiana d'Orbigny

Uvigerina isidroensis Cushman and Renz

Few to rare

Bolivina floridana Cushman

$500-1500$

Bolivina aff. marginata Cushman

$150-500$

Bolivina pisciformis Galloway and Morrey

Bolivina seminuda Cushman

$500-1500$

Bolivina spp.

Bulimina pupoides d'Orbigny 
Bulimina sp.

Cassidulina subglobosa Brady

Cibicidoides sp.

Ehrenbergina sp.

Epistominella smithi (R. E. and K. C. Stewart)

Glandulina laevigata (d'Orbigny)

Gyroidina soldanii d'Orbigny

Gyroidina sp.

Hoeglundina elegans (d’Orbigny)

Melonis affinis (Reuss)

Oridorsalis umbonatus (Reuss)

Plectofrondicularia morreyae Cushman

Plectofrondicularia sp.

Pleurostomella alternans Schwager

Siphogenerina basispinata Cushman and Jarvis

Sphaeroidina bulloides d'Orbigny

Stilostomella sp.

Uvigerina auberiana attenuata Cushman and Renz

Uvigerina rustica Cushman and Edwards

$1500-2000$

Sample 8506-25-49; present water depth, 3355-3940 m.

Tectonized mudstone with abundant, mostly benthic foraminifers and abundant radiolarians. The foraminifer assemblage is similar to that of the Chira Shale of Peru (Cushman and Stone, 1947).

Age: middle Eocene (Podocyrtis mitra radiolarian zone).

Estimated water depth: $150-2000 \mathrm{~m}$ (upper to middle bathyal).

Planktonic foraminifers

Rare

Chiloguembelina cubensis (Palmer)

Chiloguembelina venezuelana Nuttall

Clavigerinella $\mathrm{cf}$. jarvisi (Cushman) - chamber elongations only

Subbotina sp.

Truncorotaloides collactea (Finlay)

Benthic foraminifers

\author{
Abundant \\ Bulimina chirana Cushman and Stone \\ Bulimina peruviana Cushman and Stone \\ Gavelinella peruviana (Cushman and Stone) \\ Cassidella restinensis (Berry) \\ Stilostomella curvatura Cushman
}

Common

Bulimina macilenta

$500-1500$

Plectofrondicularia packardi Cushman and Schenck

Plectofrondicularia capitana (Cushman and Stone)

Stichosassidulina thalmanni Stone

Valvulineria compressa Stone

Valvulineria tumeyensis Cushman and Simonson

Water

depth $(\mathrm{m})$

$1500-2000$

$1500-2000$

$50-150$

Few to rare

Alabamina dissonata (Cushman and Renz)

Anomalina chirana Cushman and Stone

Asterigerina crassaformis Cushman and Siegfus

Bolivina cf. alazanensis Cushman

$150-500$

Bolivina carinata Terquem

Bolivina maculata Cushman and Stone

Bolivina peruviana Cushman and Stone

Bulimina minsseni Mallory

Bulimina secaensis Cushman and Stainforth

Bulimina truncanella Finlay

Buliminella chirana Cushman and Stone

Cassidulina diversa Cushman and Stone

Cibicidoides pseudoungerianus (Cushman)

Nodosaria deliciae muirensis Smith

Nodosaria longiscata d'Orbigny

Nodosaria pyrula d'Orbigny

$1500-2000$
Oridorsalis umbonatus (Reuss)

$500-1500$

Pullenia alazanesis Cushman

Spirobolivina pulchella (Cushman and Stainforth)

Stilostomella costata Hofker

Stilostomella wegemanni (Cole)

Uvigerina chirana Cushman and Stone

Radiolarians (Podocyrtis mitra Zone, middle Eocene, Moore, 1971)

Abundant

Lithocyclia ocellus

Thrysocytris triancantha

Common

Podocyrtis papalis

Few to rare

Eusyringium fistuligerum

Lithochytris vespertillio

Podocyrtis mitra

Podocyrtis trachoides

Theocampe mongolfieri

Sample 8506-30-6; present water depth, 4385-5440 m.

Sandy mudstone with radiolarians and diatoms. No foraminifers.

Age: early middle Miocene (Dorcadospyris alata radiolarian zone).

Estimated water depth: $>4000 \mathrm{~m}$ (below CCD).

Radiolarians

Common

Stichocorys delmontensis

Few to rare

Calocycletta virginis

Cannartus mammiferus

Sample 8506-32-2; present water depth, 3312-4285 m.

Radiolarian-diatom mudstone with fecal pellets. No foraminifers.

Age: late Pliocene (Kling, 1978).

Estimated water depth: $>4000 \mathrm{~m}$ (below $\mathrm{CCD}$ ).

Radiolarians

Few to rare

Lamprocyrtis neoheteroporos

Spongaster tetras

Theocorythium vetulum

Sample 8506-35-11; present water depth, 930-1190 m.

Foraminifer layer, almost entirely benthic foraminifers, with a few radiolarians and diatoms.

Estimated age: late Miocene or Pliocene ( $\simeq$ Delmontian).

Estimated water depth: $500-1500 \mathrm{~m}$ (upper-middle bathyal), with some species displaced from shallower water.

Benthic foraminifers (*Delmontian association of Kleinpell, 1980; **Pliocene of Natland, 1940)

Abundant

Water

${ }^{*}$ Bolivina seminuda foraminata $\mathrm{R}$. E. and K. C. Stewart depth $(\mathrm{m})$

Common

Bolivina sinuata praevia Coryell and Mossman 500-1500

* Bulimina cf. delreyensis Cushman and Galliher

${ }^{*}$ Bulimina uvigerinaformis doanei (Kleinpell and Tipton)

**Cassidulinella pliocenica Natland

${ }^{*}$ Epistominella purisima (Bramlette)

Gyroidina keenani (Cushman and Kleinpell) 
Few to rare

Bolivina vaughani Natland

$50-150$

Buliminella curta Cushman

$50-150$

Buliminella ecuadorana Cushman and Stevenson

$50-150$

Buliminellita sp.

Cancris auricula (Fichtel and Moll)

Cassidella californiensis grandis (Cushman and Kleinpell)

$150-500$

*Ellipsoglandulina fragilis Bramlette

Epistominella subperuviana (Cushman)

$150-500$

$150-500$

Hanzawaia illingi (Nuttall)

$50-150$

*Nonion schencki Kleinpell

Nonionella miocenica Cushman

Valvulineria californica Cushman

$150-500$

Planktonic foraminifers

Rare

Globigerinita uvula

\section{APPENDIX B}

Petrology of metamorphic lithologies from Peru dredge sites on Moana Wave cruise 8506, and industry drill holes (Ballena, Delfin) near $9^{\circ} \mathrm{S}$ latitude.

\section{Sample 8506-25-47A}

Slate: very fine-grained with well-developed foliation.

Matrix is primarily micaceous (light-colored) with very fine grains of quartz(?) disseminated throughout; occasional patches of slightly coarser-grained quartz and rare sheafs of muscovite; opaque oxides occur as minute grains along foliation planes.

Sample 8506-25-47B

Metamorphosed siltstone: fine-grained with parallel alignment of elongate quartz grains; true foliation absent.

Primarily composed of fine quartz and feldspar grains; the quartz showing minor undulatory extinction and elongation of grains; feldspar shows well-developed twinning (not subjected to high temperatures); matrix is finely recrystallized intergrowth of quartz and mica; opaque oxide grains scattered throughout; rare brown biotite and rare chlorite grains.

Sample 8506-30-2A

Metapelite: fine-grained with incipient segregation of mineral phases into subparallel bands.

Fine-grained, light brown clays (?) with roughly uniform extinction segregated into bands; light brown color; fine grains of quartz with strongly developed undulatory extinction; occasional circular or slightly ovoid patches of fine-grained, apparently recrystallized, quartz (possibly recrystallized radiolarian (?); fine grains of feldspar showing well-developed twinning (not subjected to high temperature); widely disseminated opaque oxide grains of varying sizes; occasional grains of brown biotite; occasional grains of muscovite, minor chlorite, and rare red-brown spinel.

\section{Sample 8506-30-2B}

Metapelite: highly sheared, highly recrystallized, with unusual development of concentric fracture concentration over part of the sample; a gradual change from roughly lenticular alignment of alternating bands of pelite and recrystallized material to the separation of recrystallized material by distinctly curvilinear bands of pelite can be seen within a single thin section; the fabric of the rock resembles, on a fine scale, that observed in the development of flaser structures in clay-rich carbonate strata, although the original composition of the rock was clearly pelitic; little is known of the details of flaser development; these structures are thought to result from a mechanical redistribution of the clay component of carbonate sediment as a con- sequence of increasing lithostatic pressure; in the case of this rock, if the structures are not developed as a result of overburden pressures, they most likely represent cataclasis; development of lenticular structures in scaly mudstones and siltstones is an example of the results of cataclastic stresses. To determine the conditions under which these peculiar structures developed in the rock, an assessment of the local stresses should be attempted. Probably the best way to attempt this is to study the composition and structures of samples from deeper in the forearc, where this sample was dredged. Stratigraphic relationships of samples from this area would be critical to understanding the development of these structures in the rocks.

Matrix of recrystallized fine-grained quartz intergrowths with pale yellow-brown micas(?) with widely disseminated fine grains of chlorite; separated by subparallel to lenticular to circular bands of pelite and dark brown clays; the pelite is extremely fine-grained, shows fine scale banding, and contains small grains of quartz with undulatory extinction, feldspar, fine-to-minute grains of opaque mineral (oxides?).

References for flaser structure development and photographs of incipient flaser development within DSDP Site 516 can be obtained from Coulbourn (1983).

References for scaly mudstones and lenticular structures in sheared mudstones and photomicrographs of these can be obtained from descriptions of mudstones from DSDP Site 78A (p. 535).

Sample 8506-34-1

Biotite gneiss: banding of quartz and feldspar layers containing coarse grains, interlayered with bands of medium- to fine-grained quartz, feldspar, and biotite.

Coarse- to fine-grained quartz with undulatory extinction; plagioclase with well-developed twinning (not subjected to high temperatures); brown biotite grains containing zircon inclusions with welldeveloped radiation halos; opaque oxide grains disseminated throughout rock; minor muscovite and minor overgrowth of chlorite on biotite.

Sample 8506-34-2

Biotite gneiss: bands of coarse-grained quartz and feldspar, alternating with medium- to fine-grained quartz, feldspar, and biotite.

Quartz with undulatory extinction and feldspar with well-developed twinning (not subjected to high temperature); grains of brown biotite with zircon inclusions having well-developed radiation halos; some overgrowth of chlorite on biotite; some clinozoisite and minor oxides disseminated throughout.

Sample 8506-35-17A

Muscovite biotite schist: alternating layers of predominantly quartz and feldspar grains with muscovite and biotite sheafs.

Quartz with undulatory extinction; feldspar with well-developed twinning (not subjected to high temperatures); brown biotite with chlorite overgrowths (not in equilibrium); zircon inclusions in biotite having well-developed radiation halos (old); opaque minerals disseminated throughout; minor clinozoisite.

(Originally, rock may have been either igneous extrusive or a greywacke.)

Ballena

Biotite muscovite schist: alternating layers of coarse quartz and feldspar grains with sheafs of muscovite and brown biotite (some with chlorite centers).

Quartz with undulatory extinction; feldspar with well-developed twinning (not subjected to high temperature); muscovite and chlorite 
with overgrowths of brown biotite; andalusite opaque oxides disseminated throughout the micaceous layers.

Delfin

Mica phyllite: segregation of fine granular quartz-feldspar layers and micaceous layers; the micaceous layers show evidence of internal stress; distortion of the parallelism of the long axes of the sheafs into $s$-shaped bends occurs in some layers.

Quartz with poorly developed undulatory extinction; fine grains of feldspar, muscovite, and opaque oxides disseminated throughout.

(Probably, first a fine-grained siltstone.)

\section{APPENDIX C}

Mineralogy and stable isotope geochemistry of carbonate lithologies from Peru dredge sites on Moana Wave cruise 8506.

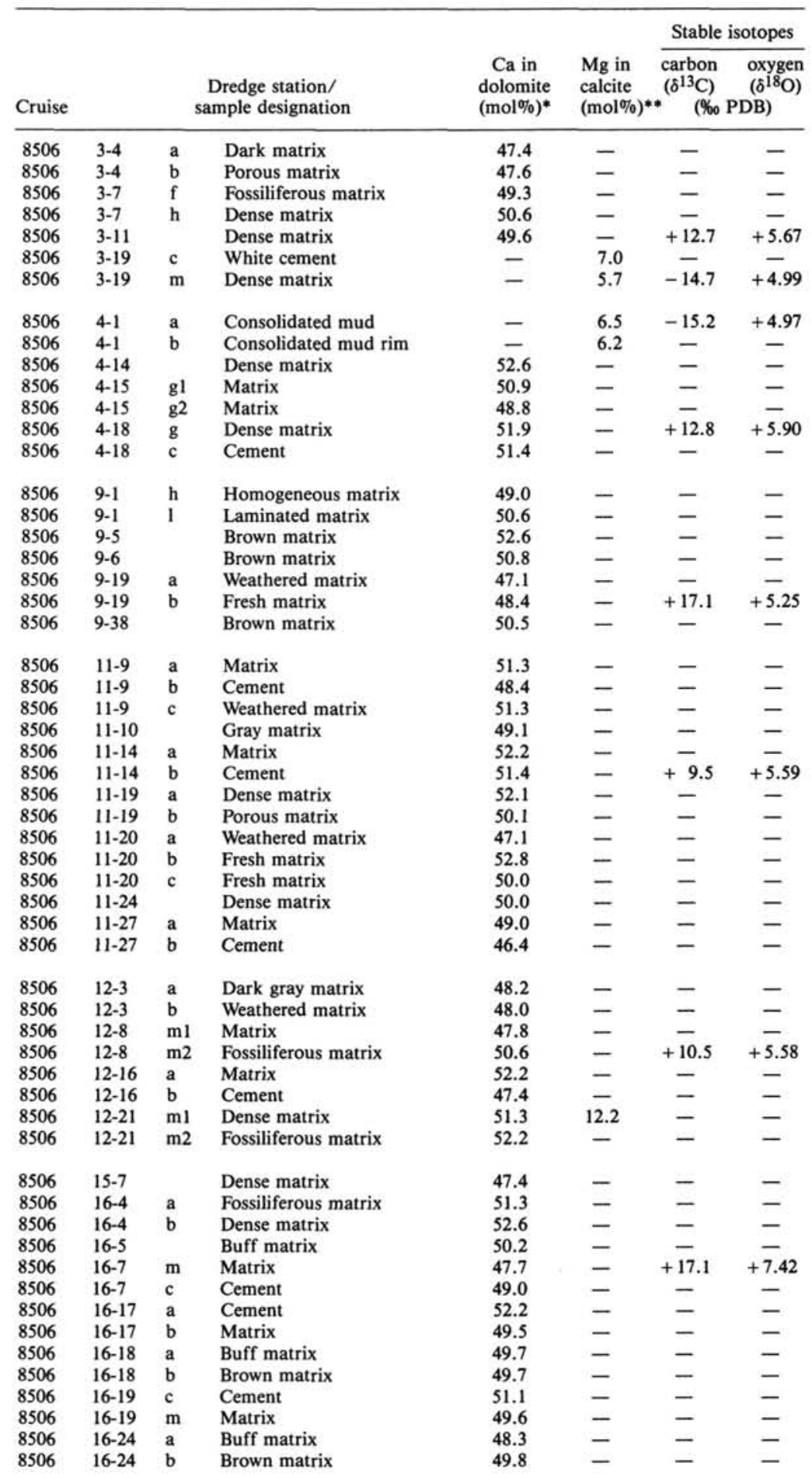


Appendix C (continued)

\begin{tabular}{|c|c|c|c|c|c|c|c|}
\hline \multirow[b]{2}{*}{ Cruise } & \multirow{2}{*}{\multicolumn{3}{|c|}{$\begin{array}{l}\text { Dredge station/ } \\
\text { sample designation }\end{array}$}} & \multirow[b]{2}{*}{$\begin{array}{c}\mathrm{Ca} \text { in } \\
\text { dolomite } \\
(\mathrm{mol} \%)^{*}\end{array}$} & \multirow[b]{2}{*}{$\begin{array}{l}\mathrm{Mg} \text { in } \\
\text { calcite } \\
(\mathrm{mol} \%)^{*}\end{array}$} & \multicolumn{2}{|c|}{ Stable isotopes } \\
\hline & & & & & & $\begin{array}{l}\text { carbon } \\
\left(\delta^{13} \mathrm{C}\right) \\
{ }^{4} \% \mathrm{P}_{0} \mathrm{P}\end{array}$ & $\begin{array}{l}\text { oxygen } \\
\left(\delta^{18} \mathrm{O}\right) \\
\mathrm{DB})\end{array}$ \\
\hline 8506 & $17-10$ & c & Cement & 47.2 & - & - & - \\
\hline 8506 & $17-10$ & $\mathrm{~m}$ & Matrix & 48.5 & - & - & - \\
\hline 8506 & $17-11$ & & Matrix & 47.4 & - & +17.7 & +7.07 \\
\hline 8506 & $18-6$ & c & Cement & - & 5.8 & - & - \\
\hline 8506 & $18-6$ & $\mathrm{~m}$ & Matrix & - & 5.3 & - & - \\
\hline 8506 & $18-9$ & & Gray matrix & 49.0 & - & - & - \\
\hline 8506 & $18-10$ & a & Matrix & 52.2 & 10.1 & -32.7 & +5.83 \\
\hline 8506 & $18-10$ & b & Cement & - & 9.3 & - & - \\
\hline 8506 & $18-12$ & a & Buff matrix & - & 10.4 & - & - \\
\hline 8506 & $18-12$ & b & Dark matrix & - & 8.9 & - & - \\
\hline 8506 & $18-12$ & c & Vein cement & - & 11.2 & - & - \\
\hline 8506 & $18-15$ & $\mathrm{~m}$ & Dense matrix & 47.2 & - & - & - \\
\hline 8506 & $18-15$ & f & Fossil matrix & 47.1 & - & +13.4 & +5.65 \\
\hline 8506 & $18-16$ & c & Gray/white cement & - & - & - & - \\
\hline 8506 & $18-16$ & $\mathrm{~m}$ & Brown matrix & 50.6 & - & - & - \\
\hline 8506 & $18-21$ & c & Gray/white cement & - & 6.0 & - & - \\
\hline 8506 & $18-21$ & $\mathrm{~m}$ & Gray/brown matrix & - & 6.0 & -33.8 & +5.63 \\
\hline 8506 & $25-1$ & & Cemented sandstone & 50.6 & - & +13.1 & +4.76 \\
\hline 8506 & $25-12$ & & Cemented sandstone & - & 10.5 & +1.5 & -1.52 \\
\hline 8506 & $25-13$ & & Cemented sandstone & 49.0 & 9.6 & - & - \\
\hline 8506 & $25-39$ & & Cemented sandstone & - & 8.3 & - & - \\
\hline 8506 & $25-48$ & sc & Fibrous cement & - & 2.8 & -3.9 & -2.31 \\
\hline 8506 & $25-48$ & wc & White cement & - & 4.9 & - & - \\
\hline 8506 & $34-7$ & 1 & Phosphorite, laminated & - & - & - & - \\
\hline 8506 & $34-7$ & h & Phosphorite, homogeneous & - & - & - & - \\
\hline 8506 & $35-1$ & $\mathrm{~h}$ & Dense matrix & - & 5.1 & - & - \\
\hline 8506 & $35-1$ & 1 & Laminated matrix & - & 4.6 & - & - \\
\hline 8506 & $35-2$ & & Gray matrix & - & 6.6 & - & - \\
\hline 8506 & $35-3$ & & Fossiliferous matrix & - & 4.9 & +10.2 & +1.50 \\
\hline 8506 & $35-6$ & cl & White cement & - & 3.7 & - & - \\
\hline 8506 & $35-6$ & c2 & Brown cement & 47.4 & 5.3 & - & - \\
\hline 8506 & $35-6$ & $\mathrm{~m}$ & Brown matrix & - & 6.3 & -29.7 & +3.45 \\
\hline 8506 & $35-8$ & a & Dense matrix & - & 6.2 & - & - \\
\hline 8506 & $35-8$ & b & Fossiliferous matrix & - & 6.4 & - & - \\
\hline 8506 & $35-10$ & c & White cement & - & 3.7 & - & - \\
\hline 8506 & $35-10$ & $\mathrm{~m}$ & Dark matrix & - & 6.3 & - & - \\
\hline 8506 & $35-11$ & d & Dense matrix & - & 5.5 & -37.3 & +2.63 \\
\hline 8506 & $35-11$ & f & Fossiliferous matrix & - & 5.0 & - & - \\
\hline 8506 & $35-11$ & v & Vein cement & - & 5.0 & - & - \\
\hline 8506 & $35-14$ & a & Dense brown matrix & - & 7.7 & - & - \\
\hline 8506 & $35-14$ & b & Fossiliferous matrix & - & 8.3 & -29.8 & +3.11 \\
\hline
\end{tabular}

- The mol\% listed indicates how far dolomite in dredged samples deviates from the ideal stoichiometric composition of $50 \mathrm{~mol} \% \mathrm{CaCO}_{3}$ and $50 \mathrm{~mol} \% \mathrm{MgCO}_{3}$.

** The mol\% listed indicates how far calcite in dredged samples deviates from pure calcite of 0 $\mathrm{mol} \% \mathrm{MgCO}_{3}$. 